Article

\title{
He-Ar-S Isotopic Compositions of Polymetallic Sulphides from Hydrothermal Vent Fields along the Ultraslow-Spreading Southwest Indian Ridge and Their Geological Implications
}

\author{
Yan Wang $1,2,+$, Zhongwei $\mathrm{Wu}^{2,+}$, Xiaoming Sun ${ }^{2,3,4, *}$, Xiguang Deng ${ }^{5}$, Yao Guan ${ }^{3} \oplus$, Li Xu ${ }^{2}$, \\ Yi Huang ${ }^{1,2}$ and Kaijun Cao ${ }^{3,5}$ \\ 1 South China Sea Institute of Planning and Environmental Research, State Oceanic Administration, \\ Guangzhou 510300, China; we85289786@163.com (Y.W.); hyggyouxiang@126.com (Y.H.) \\ 2 School of Marine Sciences, Sun Yat-sen University, Guangzhou 510006, China; figowzwpig@163.com (Z.W.); \\ xu-bluesky@126.com (L.X.) \\ 3 School of Earth Sciences and Engineering, Sun Yat-sen University, Guangzhou 510275, China; \\ guanyao@mail2.sysu.edu.cn (Y.G.); caokjyeah@163.com (K.C.) \\ 4 Guangdong Provincial Key Laboratory of Marine Resources and Coastal Engineering, Guangzhou 510006, China \\ 5 Guangzhou Marine Geological Survey, Guangzhou 510760, China; dengxg68@163.com \\ * Correspondence: eessxm@mail.sysu.edu.cn; Tel.: +86-020-84110968 \\ + These authors contributed equally to this work.
}

Received: 28 August 2018; Accepted: 5 November 2018; Published: 7 November 2018

\begin{abstract}
Noble gases have become a powerful tool to constrain the origin and evolution of ore-forming fluids in seafloor hydrothermal systems. The aim of this study was to apply these tracers to understand the genesis of newly discovered polymetallic sulphide deposits along the ultraslow-spreading Southwest Indian Ridge (SWIR). The helium, argon, and sulphur isotope compositions of metal sulphide minerals were measured for a number of active/inactive vent fields in the Indian Ocean. The helium concentrations and isotopic ratios in these ore samples are variable $\left({ }^{4} \mathrm{He}: 0.09-2.42 \times 10^{-8} \mathrm{~cm}^{3} \mathrm{STP} \cdot \mathrm{g}^{-1} ;{ }^{3} \mathrm{He}: 0.06-3.28 \times 10^{-13} \mathrm{~cm}^{3} \mathrm{STP} \cdot \mathrm{g}^{-1} ;{ }^{3} \mathrm{He} /{ }^{4} \mathrm{He}: 1.12-9.67 \mathrm{R}_{\mathrm{a}}\right)$ and generally greater than the modern atmosphere, but significantly lower than those in massive sulphides from the fast-spreading East Pacific Rise (EPR), especially for three Cu-Fe-rich samples from the ultramafic-hosted Tianzuo and Kairei vent fields. On the contrary, most of the SWIR sulphide deposits have somewhat higher ${ }^{40} \mathrm{Ar} /{ }^{36} \mathrm{Ar}$ ratios of trapped fluids (ranging from 290.6 to 303.4) when compared to the EPR ore samples. Moreover, the majority of sulphide minerals from the Indian Ocean have much higher $\delta^{34} S$ values (3.0\%o-9.8\%, $\sim 5.9$ on average, $\left.n=49\right)$ than other basaltic-hosted active hydrothermal systems on the EPR. Overall, these He-Ar-S results are well within the range of seafloor massive sulphide deposits at global sediment-starved mid-ocean ridges (MORs), lying between those of air-saturated water (ASW) and mid-ocean ridge basalt (MORB) end members. Therefore, our study suggests that the helium was derived mainly from the MORB mantle by degassing during the high-temperature stage of hydrothermal activity, as well as from a mixture of vent fluids with variable amounts of ambient seawater during either earlier or late-stage low-temperature hydrothermal episodes, whereas the argon in ore-forming fluids trapped within sulphide minerals was predominantly derived from deep-sea water. Additionally, relatively high $\delta^{34} S$ values exhibit a great estimated proportion (up to nearly $40 \%$ ) of seawater-derived components. In summary, sub-seafloor extensive fluid circulation, pervasive low-temperature alteration, shallow seawater entrainment, and mixing processes, may make a larger contribution to the SWIR hydrothermal ore-forming systems, compared to fast-spreading centres.
\end{abstract}

Keywords: He-Ar-S isotopes; massive sulphides; hydrothermal fluids; Southwest Indian Ridge 


\section{Introduction}

Over the past 40 years, submarine hydrothermal venting and associated polymetallic massive sulphides have been found in a variety of tectonic settings on the modern seafloor, including mid-ocean ridges (MORs) with different spreading rates [1-6], back-arc basins, and rift environments [7-11]. These sulphide deposits represent an immense potential reservoir of various important metal resources, such as $\mathrm{Fe}, \mathrm{Cu}, \mathrm{Zn}, \mathrm{Pb}, \mathrm{Au}$, and $\mathrm{Ag}$, thus attracting worldwide attention and research interest [12-14]. However, relatively little is known about the metallogenic characteristics of massive sulphide deposits from the Indian Ocean [15-18]. In particular, because of their remote locations, ancient and active hydrothermal systems on the ultraslow-spreading Southwest Indian Ridge (SWIR) have been much less extensively explored until recently [19-25], when compared to those well-investigated vent sites located along the fast-spreading East Pacific Rise (EPR), and the slow-spreading Mid-Atlantic Ridge (MAR) [1-4]. Although preliminary geochemical analyses of sulphide samples and the sporadic occurrence of gold have been reported in several newly discovered hydrothermal fields near the SWIR $49^{\circ}-51^{\circ}$ E region [26-30], there is only little data on the physicochemical properties of local vent fluids which may be distinct from other categories of ocean ridges [31]. Furthermore, what was the source of ore-forming fluids in such a unique geologic setting, and how did the fluids evolve through multiple stages of hydrothermal circulation, remain poorly understood.

The application of noble gas (including helium and argon) isotope geochemistry is a key to defining the origin of fluids, which can help us to answer the above questions. Helium is one of the most sensitive and indicative geochemical tracers for such studies as it is chemically inert (e.g., ${ }^{3} \mathrm{He}$ behaves extremely conservatively during mixing of vent fluids with entrained seawater) and has distinct isotopic signatures in different types of geological reservoirs [32-36]. It has been well established that, in MOR end-member fluids, ${ }^{3} \mathrm{He}$ is significantly enriched over air-saturated seawater, with ${ }^{3} \mathrm{He} /{ }^{4} \mathrm{He}$ ratios between about 7 and 9 . These ratios represent typical mantle values and correspond to ${ }^{3} \mathrm{He}$ originating from the MOR magma chambers that has degassed into the hydrothermal system [37-39]. The He-Ar isotopic compositions of hydrothermal fluids are faithfully preserved when trapped as fluid inclusions by mineral phases such as pyrite, sphalerite, or anhydrite, and thus can be used to reveal the degree of fluid-rock interaction, mantle degassing, magmatic, or tectonic activity [36,40-46]. Moreover, sulphur isotope features of polymetallic massive sulphides can serve as an important tool to interpret various $\mathrm{S}$ sources, multi-stage mineralisation processes, and precipitation mechanisms of seafloor hydrothermal products [47-52]. Therefore, an integrated study of the He-Ar-S isotope system allows us to further develop our understanding of submarine hydrothermal systems at ultraslow-spreading ridges.

\section{Geologic Setting}

The Southwest Indian Ridge (SWIR), a divergent tectonic boundary separating the African and Antarctic plates, is among the world's slowest spreading ridges with an average rate of only 14-15 mm/yr [53,54]. It extends $\sim 7700 \mathrm{~km}$ from the Bouvet to the Rodriguez Triple Junction (RTJ), and is characterised by asymmetric (oblique/orthogonal) spreading, numerous large non-transform offsets, intermittent volcanism, thin crust, and extensive outcrops of serpentinised peridotite or gabbro exposed by extensional detachment faulting [55-58]. Distinct variations have been observed in axial topography, segmentation patterns, crustal thickness, mantle composition, and melt supply along the strike, from west to east [24,59-66]. It also displays a surprisingly diverse range of seafloor morphology with highly segmented geometry, from long stretches of amagmatic rift valleys to areas with strongly focused magmatism [67-70]. Notably, along-axis geophysical anomalies indicate a complex interaction of the eastern central SWIR with the nearby Marion-Del Cano-Crozet hotspot group, which might have a significant effect on accretionary processes and tectonics of this ultraslow-spreading ridge system [71-74]. Such hotspot-ridge interaction and localised volcanism in some segments make it possible for hydrothermal vent systems to have heat sources and fluid flow channels, which can 
provide favourable conditions for hydrothermal activity, as well as the formation of massive sulphide deposits [75]. In summary, geological background of the SWIR exhibits high complexity and variability.

As shown in Figure 1, our study area is mainly located between the Indomed and Gallieni fracture zones (FZs) at the central eastern portion of the SWIR ( 900 km north of the Crozet hotspot), where sediment-starved ridge segments 27-29 lie at a high angle to the regional spreading direction [24]. Shallow depth and thicker crust than the adjacent areas reveal that this region has experienced a dramatic increase in magma supply since 10-8 Ma [67,68,71-74]. From 2007 to 2010, a number of active/inactive hydrothermal fields have been discovered consecutively in this ridge section $\left(49^{\circ}-52^{\circ} \mathrm{E}\right)$, including Longqi, Duanqiao, and Yuhuang, which are located at $49^{\circ} 39^{\prime} \mathrm{E} / 37^{\circ} 47^{\prime} \mathrm{S}$, $50^{\circ} 24^{\prime} \mathrm{E} / 37^{\circ} 39^{\prime} \mathrm{S}$, and $49^{\circ} 16^{\prime} \mathrm{E} / 37^{\circ} 56^{\prime} \mathrm{S}$, respectively $[23,24,76]$. The Longqi $\left(49.6^{\circ} \mathrm{E}\right)$ vent field is located at the high mound on the southeast wall of the ridge valley at a depth of $1755 \mathrm{~m}$, which lies on the junction point of a small non-transform offset and ridge valley [23]. Oceanic core complexes form when long-lived detachment faults expose intrusive and ultramafic rocks at the seafloor, which are very ubiquitous on the slow- or ultraslow-spreading ridges, and also important for the structural control of hydrothermal activity (i.e., by providing a pathway and heat source for fluid circulation) $[24,77,78]$. The Duanqiao $\left(50.5^{\circ} \mathrm{E}\right)$ field lies on an axial highland with a shallow depth of $\sim 1700 \mathrm{~m}$. Seafloor morphology of the surrounding terrain is relatively flat [79]. Hydrothermal precipitates, including silica-rich metalliferous sediments (mostly amorphous opal), relict chimneys, and massive sulphide talus, are pervasive in this inactive field [23,80]. The Yuhuang $\left(49.2^{\circ} \mathrm{E}\right)$ field is situated on the south rift wall of segment 29 , approximately $7.5 \mathrm{~km}$ from the ridge axis with a water depth ranging from 1400 to $1600 \mathrm{~m}$. Its surrounding terrain exhibits NEE-striking highland features, with an elevation of $\sim 1500 \mathrm{~m}$ to the bottom of the rift valley [76]. Currently, although water temperature and turbidity anomalies were not detected at Yuhuang, two sites of metal sulphide accumulations have been confirmed in this study area. Recent oceanographic surveys also suggest that there are probably outcrops of ultramafic rocks, further implying the local development of detachment faults [29]. Besides, another new hydrothermal field (Tianzuo) was found in the ridge section $63^{\circ}-64^{\circ} \mathrm{E}$ between the Melville FZ and RTJ. This ultramafic-hosted inactive site is located at $63^{\circ} 32^{\prime} \mathrm{E} / 27^{\circ} 57^{\prime} \mathrm{S}$, southwest to the relict Mt. Jourdanne field [24].

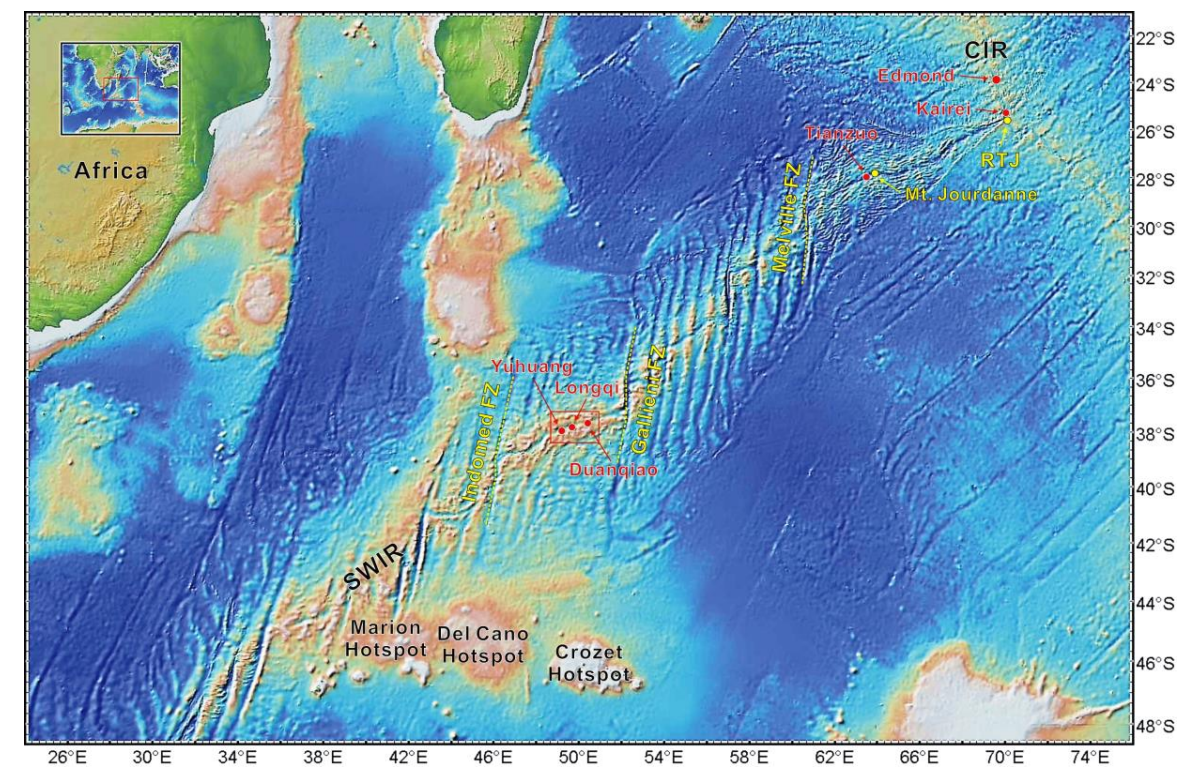

Figure 1. Location map of our study area on the Southwest Indian Ridge (between the Indomed and Gallieni fracture zones (FZs)) as well as the Central Indian Ridge (CIR) north of the Rodriguez Triple Junction (RTJ). Inset shows regional setting of the ultraslow-spreading SWIR. For more detailed bathymetry and topography data on each of these six hydrothermal fields (marked with red circles), please see the previously published literature [23,24,29,78-83]. 


\section{Sampling Information}

With the aim of exploring the SWIR hydrothermal systems, the Chinese research cruises DY115-19, DY115-20, and DY115-21 have been successfully carried out by China Ocean Mineral Resources Research \& Development Association (COMRA) during 2007-2010 [23,24,76]. Seafloor hydrothermal precipitates were collected by TV-guided grab sampler from one active vent site (Longqi) and three inactive hydrothermal fields (Duanqiao, Yuhuang, and Tianzuo) during these cruises on board the R/V Dayang Yihao. Basic information about the locations of selected sampling stations and detailed mineralogical characterisation of typical sulphide ores are described in Table 1. A suite of hand specimens represents various types of hydrothermal products recovered from the Indian Ocean ridge system, including several fragments of active/extinct "black smoker" chimneys, large blocks of massive sulphides, relict talus and oxidised debris, as well as $\mathrm{SiO}_{2}$-rich hydrothermal sediments. The morphology and occurrences of ore mineral assemblages were observed under SEM or using optical microscopy (as shown in Figure 2). Moreover, additional samples from the active mound surface of another four vent fields (Edmond, Kairei, Niaochao \& EPR $13^{\circ} \mathrm{N}$ ), at the CIR and EPR, are also included in this study for comparison. Detailed geographic data and their metallogenic features have already been well-documented in a series of published articles $[17,18,82-85]$, which are not presented here due to space limitations.

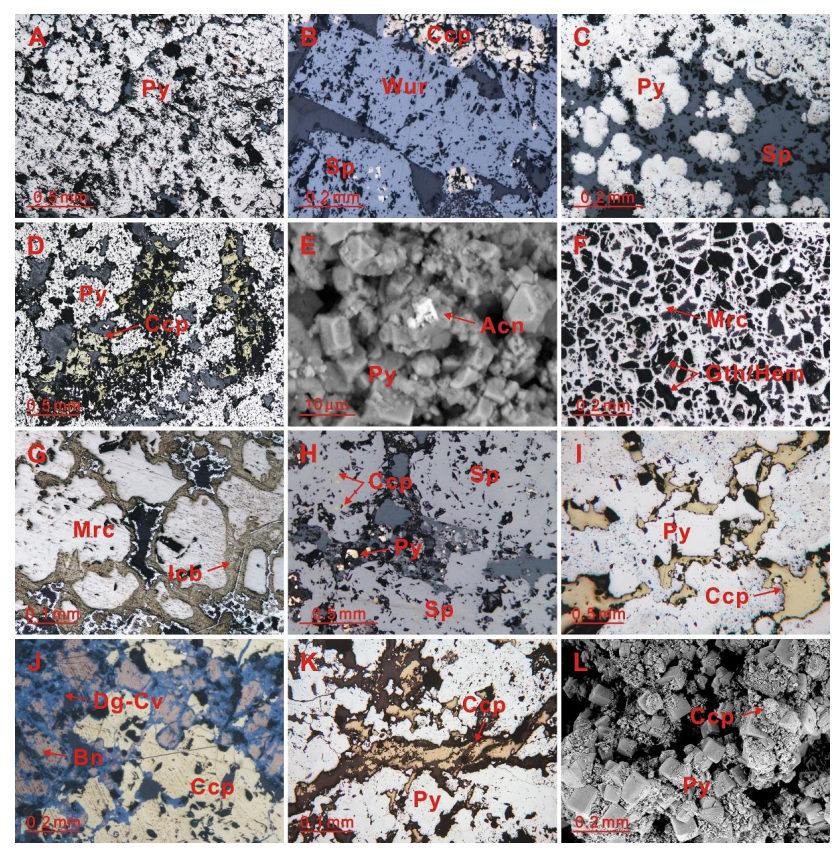

Figure 2. Reflected-light and SEM photomicrographs of typical sulphide ore types (polished thin sections or small fragments of ore specimens) from the Mid-Ocean Ridge hydrothermal vent systems. (A) Fe-rich relict sulphide talus (No. 19II-S7-TVG4A); (B) Zn-rich massive sulphide ore samples (No. 19II-S7-TVG4B); (C) Fragments of Fe-(Zn)-rich black smoker chimney walls (No. 20V-S35-TVG17); (D) Fe-(Cu)-rich relict sulphide talus (No. 20V-S32-TVG14); (E) Pyrite-dominant, silver-bearing massive sulphide ores (No. 21VII-S35-TVG22); (F,G) Marcasite-/isocubanite-bearing porous breccias coated by a thick layer of ferric oxyhydroxides and covellite (No. 20VII-S25-TVG21); (H) Zn-(Fe)-rich chimney debris coated by partially silicified crusts (No. 17A-IR-TVG12); (I) Massive blocks of Fe-Cu-rich sulphide ores dominated by pyrite (No. 19III-S18-TVG9); (J) Cu-rich massive sulphide samples, mainly consisting of chalcopyrite, bornite and secondary copper-minerals (No. 19III-S12-TVG6); (K,L) Large blocks of Fe-rich massive sulphide ores characterised by coarse-grained aggregates of euhedral to subhedral pyrite crystals (No. EPR-TVG1, EPR-TVG2 and 20III-S4-TVG1). Mineral abbreviations: $\mathrm{Acn}=$ acanthite, $\mathrm{Bn}=$ bornite, $\mathrm{Ccp}=$ chalcopyrite, $\mathrm{Cv}=$ covellite, $\mathrm{Dg}=$ digenite, $\mathrm{Gth}=$ goethite, Hem = hematite, Icb = isocubanite, Mrc = marcasite, Py = pyrite, $\mathrm{Sp}=$ sphalerite, Wur $=$ wurtzite. 
Table 1. Description of the Mid-Ocean Ridge polymetallic massive sulphides and hydrothermal sediment samples analysed for helium-argon and/or sulphur isotopic compositions in this study.

\begin{tabular}{|c|c|c|c|c|c|c|}
\hline Vent Field & Station No. & Latitude & Longitude & Depth (m) & Sample Description & Mineralogy * \\
\hline \multicolumn{7}{|c|}{ Ultraslow-spreading Southwest Indian Ridge (SWIR) } \\
\hline \multirow{5}{*}{$\begin{array}{l}\text { Longqi } \\
\left(49.6^{\circ} \mathrm{E}\right)\end{array}$} & 19II-S6-TVG3 & $49.6494^{\circ} \mathrm{E}$ & $37.7833^{\circ} \mathrm{S}$ & 2777 & Metalliferous sediments & $\mathrm{Opl}+\mathrm{Gth}+\mathrm{Hem}+\mathrm{Mg}$ \\
\hline & 19II-S7-TVG4A & $49.6495^{\circ} \mathrm{E}$ & $37.7833^{\circ} \mathrm{S}$ & 2755 & Fe-rich relict chimney debris & $\mathrm{Py}+\mathrm{Mrc}+\mathrm{Ccp}+\mathrm{Sp}$ \\
\hline & 19II-S7-TVG4B & $49.6496^{\circ} \mathrm{E}$ & $37.7834^{\circ} \mathrm{S}$ & 2781 & Zn-rich massive sulphide ores & $S p+W u r+P y+C c p$ \\
\hline & 20V-S7-TVG2 & $49.6494^{\circ} \mathrm{E}$ & $37.7843^{\circ} \mathrm{S}$ & 2795 & Si-Fe-Mn oxyhydroxides & $\mathrm{Opl}+\mathrm{Gth}+\mathrm{Mg}+\mathrm{Py}$ \\
\hline & 20V-S35-TVG17 & $49.6481^{\circ} \mathrm{E}$ & $37.7802^{\circ} \mathrm{S}$ & 2783 & Black smoker chimney fragment & $\mathrm{Py}+\mathrm{Po}+\mathrm{Sp}+\mathrm{Ccp}$ \\
\hline \multirow{4}{*}{$\begin{array}{c}\text { Duanqiao } \\
\left(50.5^{\circ} \mathrm{E}\right)\end{array}$} & 20V-S17-TVG7 & $50.4672^{\circ} \mathrm{E}$ & $37.6586^{\circ} \mathrm{S}$ & 1740 & Silica-rich relict chimney debris & $\mathrm{Opl}+\mathrm{Gth}+\mathrm{Mg}+\mathrm{Py}$ \\
\hline & 20V-S32-TVG14A & $50.4672^{\circ} \mathrm{E}$ & $37.6579^{\circ} \mathrm{S}$ & 1739 & Metalliferous sediments & $\mathrm{Py} / \mathrm{Mrc}+\mathrm{Ccp}+\mathrm{Sp}+\mathrm{Opl}$ \\
\hline & 20V-S32-TVG14B & $50.4672^{\circ} \mathrm{E}$ & $37.6579^{\circ} \mathrm{S}$ & 1739 & Fe-rich relict sulphide talus & $\mathrm{Py} / \mathrm{Mrc}+\mathrm{Ccp}+\mathrm{Sp}+\mathrm{Opl}$ \\
\hline & 20VII-S12-TVG10 & $50.468^{\circ} \mathrm{E}$ & $37.6594^{\circ} \mathrm{S}$ & 1772 & Si-Fe-Mn oxyhydroxides & $\mathrm{Opl}+\mathrm{Gth}+\mathrm{Mg}+\mathrm{Py}$ \\
\hline \multirow{2}{*}{$\begin{array}{l}\text { Yuhuang } \\
\left(49.2^{\circ} \mathrm{E}\right)\end{array}$} & 21VII-S35-TVG22A & $49.2657^{\circ} \mathrm{E}$ & $37.9389^{\circ} \mathrm{S}$ & 1445 & Fe-rich massive sulphide ores & $\mathrm{Py} / \mathrm{Mrc}+\mathrm{Po}+\mathrm{Ccp}+\mathrm{Sp}$ \\
\hline & 21VII-S35-TVG22B & $49.2649^{\circ} \mathrm{E}$ & $37.9386^{\circ} \mathrm{S}$ & 1443 & Fe-rich massive sulphide talus & $\mathrm{Py} / \mathrm{Mrc}+\mathrm{Po}+\mathrm{Ccp}+\mathrm{Sp}$ \\
\hline \multirow{2}{*}{$\begin{array}{l}\text { Tianzuo } \\
\left(63.5^{\circ} \mathrm{E}\right)\end{array}$} & 20VII-S25-TVG21A & $63.5414^{\circ} \mathrm{E}$ & $27.9507^{\circ} \mathrm{S}$ & 3666 & Fe-Cu-rich relict sulphide talus & $\mathrm{Mrc}+\mathrm{Icb}+\mathrm{Gth}+\mathrm{Cv}$ \\
\hline & 20VII-S25-TVG21B & $63.5414^{\circ} \mathrm{E}$ & $27.9507^{\circ} \mathrm{S}$ & 3666 & Fe-Cu-rich massive sulphides & $\mathrm{Mrc}+\mathrm{Icb}+\mathrm{Gth}+\mathrm{Cv}$ \\
\hline \multicolumn{7}{|c|}{ Intermediate-spreading Central Indian Ridge (CIR) } \\
\hline \multirow{2}{*}{ Emond } & 17A-IR-TVG12 & $69.5973^{\circ} \mathrm{E}$ & $23.8778^{\circ} \mathrm{S}$ & 3293 & Zn-Fe-rich chimney fragment & $\mathrm{Sp}+\mathrm{Py}+\mathrm{Opl}+\mathrm{Brt}$ \\
\hline & 19III-S18-TVG9 & $69.5975^{\circ} \mathrm{E}$ & $23.8773^{\circ} \mathrm{S}$ & 3277 & Fe-Cu-rich massive sulphides & $\mathrm{Py}+\mathrm{Ccp}+\mathrm{Mrc}+\mathrm{Brt}$ \\
\hline \multirow{2}{*}{ Kairei } & 19III-S12-TVG6 & $70.0407^{\circ} \mathrm{E}$ & $25.3205^{\circ} \mathrm{S}$ & 2443 & Cu-rich massive sulphide ores & $\mathrm{Ccp}+\mathrm{Bn}+\mathrm{Dg}+\mathrm{Cv}$ \\
\hline & 19III-S13-TVG7 & $70.0402^{\circ} \mathrm{E}$ & $23.3203^{\circ} \mathrm{S}$ & 2440 & Cu-bearing siliceous breccias & $\mathrm{Ccp}+\mathrm{Qz}+\mathrm{Tlc}+\mathrm{Cal}$ \\
\hline \multicolumn{7}{|c|}{ Fast-spreading East Pacific Rise (EPR) } \\
\hline EPR & EPR-TVG1 & $103.9071^{\circ} \mathrm{W}$ & $12.7115^{\circ} \mathrm{N}$ & 2628 & Fe-rich massive sulphide ores & $\mathrm{Py} / \mathrm{Mrc}+\mathrm{Po}+\mathrm{Ccp}+\mathrm{Sp}$ \\
\hline $13^{\circ} \mathrm{N}$ & EPR-TVG2 & $103.9069^{\circ} \mathrm{W}$ & $12.7111^{\circ} \mathrm{N}$ & 2633 & Fe-rich massive sulphide ores & $\mathrm{Py} / \mathrm{Mrc}+\mathrm{Po}+\mathrm{Ccp}+\mathrm{Sp}$ \\
\hline \multicolumn{7}{|c|}{ Superfast-spreading southern East Pacific Rise (SEPR) } \\
\hline \multirow[b]{2}{*}{ Niaochao } & 20III-S4-TVG1A & $102.456^{\circ} \mathrm{W}$ & $1.3688^{\circ} \mathrm{S}$ & 2747 & Fe-Cu-rich massive sulphides & $\mathrm{Py}+\mathrm{Mrc}+\mathrm{Ccp}+\mathrm{Sp}$ \\
\hline & 20III-S4-TVG1B & $102.456^{\circ} \mathrm{W}$ & $1.3688^{\circ} \mathrm{S}$ & 2747 & $\mathrm{Fe}-\mathrm{Cu}$-rich massive sulphides & $P y+C c p+M r c+S p$ \\
\hline
\end{tabular}

The above polymetallic sulphides, water depth and longitude/latitude data are provided by China Ocean Sample Repository. ${ }^{*}$ These minerals are roughly listed in descending order of their relative abundance. Abbreviations: $\mathrm{Bn}=$ bornite, $\mathrm{Brt}=$ barite, $\mathrm{Cal}=$ calcite, $\mathrm{Ccp}=$ chalcopyrite, $\mathrm{Cv}=$ covellite, $\mathrm{Dg}=$ digenite, $\mathrm{Gth}=$ goethite, Hem $=$ hematite, $\mathrm{Icb}=$ isocubanite, $\mathrm{Mg}=$ manganite, $\mathrm{Mrc}=$ marcasite, $\mathrm{Opl}=$ opal- $\mathrm{A}, \mathrm{Po}=$ pyrrhotite, $\mathrm{Py}=$ pyrite, $\mathrm{Qz}=$ quartz, $\mathrm{Sp}=$ sphalerite, $\mathrm{Tlc}=$ talc, Wur $=$ wurtzite 
Hydrothermal precipitates collected by TV-Grab from four sampling stations in the Longqi vent field are mainly composed of chimney wall fragments, massive sulphide ores, and silica-rich metalliferous sediments. Based on optical microscopic observations (Figure 2A-C), representative samples can be roughly classified into two major types, including Fe-rich (19II-S7-TVG4A and 20V-S35-TVG17) and Zn-rich (19II-S7-TVG4B) sulphide ores. Two mineralisation stages were also recognised by previous researchers $[26,27]$. Similarly, ore samples recovered from the adjacent Duanqiao and Yuhuang hydrothermal fields also include Fe-rich relict sulphide talus or clasts (20V-S32-TVG14 and 21VII-S35-TVG22) consisting mostly of pyrite/marcasite with minor chalcopyrite and sphalerite (Figure 2D,E), which might be derived from the recent collapse of inactive chimney edifices $[24,29,80]$. By contrast, the mineralisation style is somewhat unique at the Tianzuo field, which reflects complex ore-forming processes related to ultramafic-hosted hydrothermal environments of the ultraslow-spreading SWIR [86]. As shown in Figure 2F,G, these porous Fe-Cu-rich sulphide breccias (20VII-S25-TVG21) are principally composed of marcasite (at least two generations) and isocubanite, with a small amount of covellite, whereas pyrite and sphalerite were rarely identified. Detailed mineral assemblages and textures are also characterised by abundant Fe-oxyhydroxides filling in microcavities or fractures, which appear to have undergone extensive hydrothermal alteration and supergene weathering.

Four vent sites from the CIR and EPR are typical of hydrothermal activity at intermediate- to fast-spreading, sediment-starved oceanic ridges. Likewise, we identified two types of polymetallic sulphide samples (Figure 2H,I) from the Edmond vent field: Zn-rich layers of extinct chimney structures dominated by Fe-rich massive to euhedral sphalerite (17A-IR-TVG12), and large blocks of $\mathrm{Fe}-(\mathrm{Cu})$-rich sulphide ores with low porosity due to replacement and infilling of open space by chalcopyrite or marcasite (19III-S18-TVG9). Chalcopyrite-rich massive sulphides (19III-S12-TVG6) and talc-bearing siliceous breccias (19III-S13-TVG7) from the ultramafic-hosted Kairei vent field on the CIR were studied in order to compare their isotopic composition with that of the Tianzuo field. In contrast to the strongly altered Kairei samples with abundant secondary Cu-minerals (Figure 2J), Fe-rich primary sulphide ores (EPR-TVG1, EPR-TVG2, and 20III-S4-TVG1) from the EPR active vent sites were probably formed during the main stage of $\sim 350{ }^{\circ} \mathrm{C}$ hydrothermal activity, which represent inner-wall sulphide phases (pyrite-pyrrhotite-chalcopyrite) of black smoker chimneys (Figure 2K,L). In general, a series of common mineralogical associations, characterised by coarse-grained, subhedral to euhedral pyrite/pyrrhotite, chalcopyrite-isocubanite, and Fe-rich sphalerite/wurtzite, points to a high-temperature formation, while those consisting of colloform marcasite, Fe-poor sphalerite and secondary $\mathrm{Cu}$-sulphides (such as covellite-digenite), together with amorphous silica (opal-A) as well as poorly crystalline $\mathrm{Fe}-\mathrm{Mn}$ oxyhydroxides, indicate a formation under lower temperatures during either earlier or late-stage hydrothermal episodes.

\section{Analytical Methods}

Selected fragments of representative hand specimens $(n=21)$ were coarsely crushed into millimetre-sized granules using agate mortar and pestle. In particular, some chimney walls (such as 19II-S7-TVG4, 20V-S35-TVG17, and 21VII-S35-TVG22) were divided into the interior conduit portions and outer layers, and then cut into pieces of subsamples according to the observed spatial zonation of mineral assemblages. To obtain homogeneous microcrystalline groundmass separates, various types of metal sulphide phases with small diameters (20-60 mesh size fraction) were carefully hand-picked under a binocular microscope. However, it should be noted that a clean separation of pyrite/marcasite, chalcopyrite, and sphalerite was almost impossible to achieve, due to intimate intergrowths of fine-grained sulphide aggregates. Helium and argon isotopic compositions of trapped hydrothermal fluids from the Indian Ocean massive sulphide deposits were determined with an all-metal extraction line and a GV-5400 noble gas mass spectrometer (GV Instruments, UK) at the State Key Laboratory of Ore Deposit Geochemistry, Institute of Geochemistry, Chinese Academy of Sciences (Guiyang). For higher precision, a number of subsamples (denoted by * as shown in Table 2) were 
further analysed using a Thermo Fisher Helix Split Flight Tube (SFT) multi-collector mass spectrometer at the Analytical Laboratory of Beijing Research Institute of Uranium Geology.

Detailed sample preparation procedures and experimental methods used here were similar to those described in references [87-89]. Approximately 0.1-0.5 g of coarse-grained (generally $0.2-1.0 \mathrm{~mm}$ ) hand-picked mineral separates were first cleaned ultrasonically several times in alcohol, then dried in vacuo and loaded in on-line crusher buckets. In order to remove adhered atmospheric gases, these samples were baked at about $150{ }^{\circ} \mathrm{C}$ in an ultra-high vacuum system for $>24 \mathrm{~h}$ prior to measurement. Fluid inclusion-hosted volatiles were released from mineral grains into the all-metal extraction system by sequential crushing in modified Nupro-type valves. The released gases were exposed to a titanium sponge furnace at $800{ }^{\circ} \mathrm{C}$ for $20 \mathrm{~min}$ to remove the bulk of active gases (e.g., $\mathrm{CO}_{2}$ and $\mathrm{H}_{2} \mathrm{O}$ ), and then exposed to two SAES $\mathrm{Zr}-\mathrm{Al}$ getters (one at room temperature, the other at $450{ }^{\circ} \mathrm{C}$ ) for $10 \mathrm{~min}$ to further purify. He was separated from Ar using an activated charcoal cold finger at liquid $\mathrm{N}_{2}$ temperature $\left(\sim 196{ }^{\circ} \mathrm{C}\right)$ for $40-60 \mathrm{~min}$ to trap Ar, then $\mathrm{He}$ and Ar isotopes were analysed using the GV-5400 or Helix SFT with relative errors of $<10 \%$. Procedural blanks (below $2 \times 10^{-10} \mathrm{~cm}^{3} \mathrm{STP}{ }^{4} \mathrm{He}$ and $2-4 \times 10^{-10} \mathrm{~cm}^{3} \mathrm{STP}{ }^{40} \mathrm{Ar}$ ) were insignificant. Noble gas abundances were measured by peak-height comparison with known amounts of standard air from an air bottle. The atmospheric ${ }^{3} \mathrm{He} /{ }^{4} \mathrm{He}$ and ${ }^{40} \mathrm{Ar} /{ }^{36} \mathrm{Ar}$ ratio is $1.399 \times 10^{-6}$ and 295.5 , respectively [90].

S-isotope measurements of fifty-five subsamples from eight different hydrothermal vent fields were performed on a Thermo-Finnigan MAT-253 isotope-ratio mass spectrometer (IRMS) at the Analytical Laboratory of Beijing Research Institute of Uranium Geology (China). For more details on experimental methods and instrumental operating parameters, please see [91]. Sulphur isotopic compositions are reported in per mil (\%) relative to the Vienna-Canyon Diablo Troilite (V-CDT) standard. In this study, our data were calibrated against the GBW-04414 and GBW-04415 silver sulphides which were used as certified reference materials (Chinese national standards, according to $\mathrm{DZ} / \mathrm{T}$ 0184.14-1997) with $\delta^{34} \mathrm{~S}$ values of $-0.07 \% 0 \pm 0.13 \%$ and $22.15 \% 0 \pm 0.14 \%$, respectively. The overall analytical precision is better than $\pm 0.2 \%$.

\section{Results}

\subsection{Helium-Argon Concentrations and Isotopic Ratios}

As presented in Table 2, the measured abundances of fluid inclusion-hosted helium and argon in these hydrothermal sulphide samples $(n=13)$ vary over three orders of magnitude (e.g., ${ }^{4} \mathrm{He}: 0.09-9.70$ $\times 10^{-8} \mathrm{~cm}^{3} \mathrm{STP} \cdot \mathrm{g}^{-1}{ }^{3} \mathrm{He}: 0.06-12.90 \times 10^{-13} \mathrm{~cm}^{3} \mathrm{STP} \cdot \mathrm{g}^{-1} ;{ }^{40} \mathrm{Ar}: 0.28-5.26 \times 10^{-6} \mathrm{~cm}^{3} \mathrm{STP} \cdot \mathrm{g}^{-1} ;{ }^{36} \mathrm{Ar}$ : $\left.0.95-17.53 \times 10^{-9} \mathrm{~cm}^{3} \mathrm{STP} \cdot \mathrm{g}^{-1}\right)$. By comparison, Fe-rich massive sulphide ores from the EPR $13^{\circ} \mathrm{N}$ contain the highest ${ }^{3} \mathrm{He}$ and ${ }^{4} \mathrm{He}$ concentrations among the entire suite of tested samples, which are significantly higher than the Indian Ocean polymetallic sulphides (especially for those $\mathrm{Cu}-\mathrm{Fe}$-rich samples from ultramafic-hosted hydrothermal systems along the SWIR and CIR). On the contrary, most of the ${ }^{36} \mathrm{Ar}$ and ${ }^{40} \mathrm{Ar}$ contents in sulphide mineral aggregates from the ultraslow-spreading SWIR are generally higher than those from superfast- to intermediate-spreading ridges (such as Niaochao and Kairei samples). Moreover, we should also note that such variations in He contents may be attributed to differences in the actual size and population densities of fluid inclusions among various sulphide minerals, or even due to the variation in crushing/degassing efficiency (to a certain extent) [36,41]. 
Table 2. He-Ar concentrations $\left(\mathrm{cm}^{3} \mathrm{STP} / \mathrm{g}\right)$ and isotopic compositions of fluid inclusions hosted in seafloor polymetallic massive sulphides from the Mid-Ocean Ridge hydrothermal vent systems.

\begin{tabular}{|c|c|c|c|c|c|c|c|c|}
\hline Location & Sample No. & Mineral & ${ }^{4} \mathrm{He}\left(10^{-8} \mathrm{~cm}^{3} \mathrm{STP} / \mathrm{g}\right)$ & ${ }^{3} \mathrm{He}\left(10^{-13} \mathrm{~cm}^{3} \mathrm{STP} / \mathrm{g}\right)$ & ${ }^{3} \mathrm{He} /{ }^{4} \mathrm{He}\left(\mathrm{R}_{\mathrm{a}}\right)$ & ${ }^{40} \mathrm{Ar}\left(10^{-6} \mathrm{~cm}^{3} \mathrm{STP} / \mathrm{g}\right)$ & ${ }^{36} \mathrm{Ar}\left(10^{-9} \mathrm{~cm}^{3} \mathrm{STP} / \mathrm{g}\right)$ & ${ }^{40} \mathrm{Ar} /{ }^{36} \mathrm{Ar}$ \\
\hline \multirow{3}{*}{$\begin{array}{c}\text { Longqi } \\
\left(\text { SWIR } 49.6^{\circ} \mathrm{E}\right)\end{array}$} & 19II-S7-TVG4A * & Py + Ccp & 1.30 & 1.02 & $5.63 \pm 0.07$ & 1.49 & 5.14 & $290.6 \pm 0.20$ \\
\hline & 19II-S7-TVG4B & $S p+W u r$ & $1.74 \pm 0.03$ & $2.22 \pm 0.07$ & $9.10 \pm 0.33$ & $2.02 \pm 0.01$ & $6.78 \pm 0.05$ & $298.4 \pm 2.65$ \\
\hline & 20V-S35-TVG17 & $\mathrm{Py}+\mathrm{Sp}$ & $2.42 \pm 0.04$ & $3.28 \pm 0.11$ & $9.67 \pm 0.36$ & $4.38 \pm 0.03$ & $14.80 \pm 0.10$ & $296.0 \pm 2.59$ \\
\hline $\begin{array}{c}\text { Duanqiao } \\
\left(\text { SWIR } 50.5^{\circ} \mathrm{E}\right)\end{array}$ & 20V-S32-TVG1 * & Py + Ccp & 2.20 & 2.62 & $8.56 \pm 0.07$ & 1.40 & 4.62 & $302.2 \pm 0.45$ \\
\hline $\begin{array}{c}\text { Yuhuang } \\
\left.\text { (SWIR } 49.2^{\circ} \mathrm{E}\right)\end{array}$ & 21VII-S35-TVG22 & Py + Po & $1.83 \pm 0.03$ & $2.33 \pm 0.11$ & $9.11 \pm 0.43$ & $1.26 \pm 0.01$ & $4.26 \pm 0.03$ & $295.1 \pm 2.87$ \\
\hline \multirow{2}{*}{$\begin{array}{c}\text { Tianzuo } \\
\left(\text { SWIR } 63.5^{\circ} \mathrm{E}\right)\end{array}$} & 20VII-S25-TVG21A & $\mathrm{Mrc}+\mathrm{Icb}$ & $0.54 \pm 0.01$ & $0.084 \pm 0.009$ & $1.12 \pm 0.12$ & $5.26 \pm 0.03$ & $17.53 \pm 0.14$ & $300.2 \pm 3.01$ \\
\hline & 20VII-S25-TVG21B * & $\mathrm{Mrc}+\mathrm{Icb}$ & 0.25 & 0.066 & $1.88 \pm 0.02$ & 2.59 & 8.54 & $303.4 \pm 0.32$ \\
\hline \multirow{2}{*}{$\begin{array}{c}\text { Edmond } \\
\left(\mathrm{CIR} 69.6^{\circ} \mathrm{E}\right)\end{array}$} & 17A-IR-TVG12* & $\mathrm{Sp}+\mathrm{Py}$ & 0.81 & 0.94 & $8.35 \pm 0.09$ & 1.39 & 4.77 & $292.6 \pm 0.16$ \\
\hline & 19III-S18-TVG9 & Py + Ccp & $2.39 \pm 0.04$ & $2.69 \pm 0.07$ & $8.02 \pm 0.24$ & $1.11 \pm 0.01$ & $3.75 \pm 0.02$ & $294.8 \pm 2.59$ \\
\hline $\begin{array}{c}\text { Kairei } \\
\left(\mathrm{CIR} 70^{\circ} \mathrm{E}\right)\end{array}$ & 19III-S12-TVG6 & $\mathrm{Ccp}+\mathrm{Cv}$ & $0.085 \pm 0.002$ & $0.055 \pm 0.014$ & $4.63 \pm 1.20$ & $0.28 \pm 0.002$ & $0.95 \pm 0.02$ & $294.4 \pm 6.88$ \\
\hline \multirow{2}{*}{$\mathrm{EPR} 13^{\circ} \mathrm{N}$} & EPR-TVG1 * & $\mathrm{Py}+\mathrm{Po}$ & 9.70 & 12.90 & $9.57 \pm 0.08$ & 0.95 & 3.29 & $287.4 \pm 0.16$ \\
\hline & EPR-TVG2 * & $\mathrm{Py}+\mathrm{Po}$ & 8.90 & 12.37 & $10.0 \pm 0.12$ & 1.49 & 5.12 & $291.6 \pm 0.19$ \\
\hline $\begin{array}{c}\text { Niaochao } \\
\left(\text { SEPR } 1-2^{\circ} \text { S) }\right.\end{array}$ & 20III-S4-TVG1 * & Py + Mrc & 1.50 & 0.70 & $3.37 \pm 0.03$ & 0.36 & 1.25 & $287.6 \pm 0.26$ \\
\hline
\end{tabular}

Note: All errors are quoted at the $1 \sigma$ confidence level. For seven samples denoted by *, experimental uncertainties of their He-Ar concentration data are not given in the laboratory's test report. The atmospheric ${ }^{3} \mathrm{He} /{ }^{4} \mathrm{He}$ ratio $\left(\mathrm{R}_{\mathrm{a}}\right)$ is $\sim 1.4 \times 10^{-6}$ [90]. Abbreviations: Ccp $=$ chalcopyrite, $\mathrm{Cv}=$ covelite, Icb $=$ isocubanite, Mrc $=$ marcasite, Po $=$ pyrrhotite, Py $=$ pyrite, $\mathrm{Sp}=$ sphalerite, Wur $=$ wurtzite . 
The ${ }^{3} \mathrm{He} /{ }^{4} \mathrm{He}$ ratios in all of these hydrothermal precipitates vary from 1.12 to $\sim 10.0 \mathrm{R}_{\mathrm{a}}$, while the ${ }^{40} \mathrm{Ar} /{ }^{36} \mathrm{Ar}$ ratios range from 287.4 to 303.4 (Table 2), with an average of 294.9 close to air-saturated water (ASW: 295.5) [90]. It is worthy of note that a majority of the SWIR sulphide deposits have somewhat higher ${ }^{40} \mathrm{Ar} /{ }^{36} \mathrm{Ar}$ ratios of trapped fluids ( 298.0 on average, $n=7$ ) when compared to the EPR and CIR ore samples ( 291.4 on average, $n=6$ ). Furthermore, most of the calculated ${ }^{3} \mathrm{He} /{ }^{4} \mathrm{He}$ ratios (except for the Tianzuo inactive field) are significantly greater than the modern atmosphere, lying within the range of mid-ocean ridge basalts (MORBs: about 7-9 $R_{a}$ ) [23] or even slightly higher. Only two marcasite-dominated samples (20VII-S25-TVG21) from the SWIR near $63.5^{\circ} \mathrm{E}$ both have distinctly low ${ }^{3} \mathrm{He} /{ }^{4} \mathrm{He}$ ratios $\left(1.12-1.88 \mathrm{R}_{\mathrm{a}}\right)$ that are very close to the atmospheric end-member value [90]. Overall, there appears to be no clear trends/relationships between the ${ }^{3} \mathrm{He} /{ }^{4} \mathrm{He}$ ratios and the MOR spreading rate or water depth.

\subsection{Sulphur Isotope Compositions}

As shown in Table 3, polymetallic sulphide deposits from global MOR hydrothermal systems exhibit a relatively broad range of $\delta^{34} S$ values from $0.5 \%$ to $10.5 \%$, with an average of $\sim 5.7 \%$ ( $\left.n=55\right)$. In general, except for two unusual datapoints (i.e., the maximum and minimum values) that deviated largely from the normal $\delta^{34} \mathrm{~S}$ range, most of the sulphide minerals from the Indian Ocean have much higher S-isotope ratios (SWIR $\delta^{34} \mathrm{~S}: 3.0 \% 0-9.8 \%$, avg. $\sim 5.8, n=31$; CIR $\delta^{34} \mathrm{~S}: 5.0 \% 0-7.8 \%$, avg. $\sim 6.0, n=18)$ than those from the EPR $13^{\circ} \mathrm{N}$ and SEPR $1-2^{\circ} \mathrm{S}\left(\delta^{34} \mathrm{~S}: 1.8 \% 0-5.5 \%\right.$, avg. $\left.\sim 3.7, n=4\right)$. Noteworthily, the Longqi hydrothermal precipitates display a bimodal distribution of $S$ isotopes in two types of mineralogical assemblages (Fe-rich sulphide ores: $\delta^{34} \mathrm{~S}=5.2 \% 0-7.5 \%$, avg. $\sim 6.2$, $n=9$; Zn-rich sulphide ores: $\delta^{34} \mathrm{~S}=3.0 \% 0-4.7 \%$, avg. $\sim 3.7, n=7$ ), which are somewhat similar to the features of other MORB-hosted active hydrothermal systems on the CIR (e.g., Edmond $\delta^{34} \mathrm{~S}$ : $5.3 \% 0-7.8 \%$, avg. $\sim 6.4, n=8$ ). Furthermore, a majority of Fe-Cu-rich massive sulphide samples from the ultramafic-hosted Tianzuo inactive field are typically characterised by elevated $\delta^{34} S$ values, with an average of $\sim 9.2 \%(n=3)$. Such sulphur isotopic feature is obviously distinct from the nearby Kairei vent site ( $\delta^{34} \mathrm{~S}: 5.0 \% 0-6.2 \%$, avg. $\sim 5.7, n=10$ ) associated with ultramafic basement rocks.

Table 3. Bulk S-isotope compositions of polymetallic massive sulphides from the Mid-Ocean Ridge hydrothermal vent systems and the estimated proportional contributions of dual sulphur sources. *

\begin{tabular}{|c|c|c|c|c|c|}
\hline \multirow{2}{*}{ Sample No. } & \multirow{2}{*}{$\begin{array}{c}\text { Measured } \\
\text { Minerals }\end{array}$} & \multirow{2}{*}{$\delta^{34} S_{\mathrm{V}-\mathrm{CDT}}(\%)$} & \multirow{2}{*}{ Average $(\%)$} & \multicolumn{2}{|c|}{ Proportions of Sulphur Sources (\%) } \\
\hline & & & & Seawater-Derived & Magmatic Origin \\
\hline \multicolumn{4}{|c|}{ MORB-hosted Longqi active vent field (SWIR $49.6^{\circ}$ E) $5.1(n=16)$} & $13.1-35.0$ & $65.0-86.9$ \\
\hline 19II-S6-TVG3-1 & Py & 7.5 & \multirow{4}{*}{$6.85(n=3)$} & 35.0 & 65.0 \\
\hline 19II-S6-TVG3-2 & Ccp & 7.4 & & 34.5 & 65.5 \\
\hline 19II-S6-TVG3-3 & Bulk ore & 6.2 & & 28.6 & 71.4 \\
\hline 19II-S7-TVG4A-1 & $\mathrm{Py}+\mathrm{Mrc}$ & 5.5 & & 25.2 & 74.8 \\
\hline 19II-S7-TVG4A-2 & $\mathrm{Ccp}+\mathrm{Sp}$ & 5.6 & \multirow{3}{*}{$5.47(n=3)$} & 25.7 & 74.3 \\
\hline 19II-S7-TVG4A-3 & Bulk ore & 5.3 & & 24.3 & 75.7 \\
\hline 19II-S7-TVG4B-1 & $S p+W u r$ & 3.3 & & 14.6 & 85.4 \\
\hline 19II-S7-TVG4B-2 & Wur & 3.0 & \multirow{3}{*}{$3.23(n=4)$} & 13.1 & 86.9 \\
\hline 19II-S7-TVG4B-3 & $\mathrm{Sp}$ & 3.4 & & 15.0 & 85.0 \\
\hline 19II-S7-TVG4B-4 & $P y+S p$ & 3.2 & & 14.1 & 85.9 \\
\hline 20V-S7-TVG2 & Bulk ore & 5.2 & & 23.8 & 76.2 \\
\hline 20V-S35-TVG17-1 & $\mathrm{Py}+\mathrm{Mrc}$ & 7.0 & \multirow{5}{*}{$5.24(n=5)$} & 32.5 & 67.5 \\
\hline 20V-S35-TVG17-2 & $\mathrm{Py}+\mathrm{Po}$ & 4.1 & & 18.4 & 81.6 \\
\hline 20V-S35-TVG17-3 & Py & 6.1 & & 28.2 & 71.8 \\
\hline 20V-S35-TVG17-4 & Sp & 4.3 & & 19.4 & 80.6 \\
\hline 20V-S35-TVG17-5 & $\mathrm{Py}+\mathrm{Sp}$ & 4.7 & & 21.4 & 78.6 \\
\hline
\end{tabular}


Table 3. Cont.

\begin{tabular}{|c|c|c|c|c|c|}
\hline \multirow{2}{*}{ Sample No. } & \multirow{2}{*}{$\begin{array}{c}\text { Measured } \\
\text { Minerals }\end{array}$} & \multirow{2}{*}{$\delta^{34} S_{\text {V-CDT }}(\%)$} & \multirow{2}{*}{ Average $(\%)$} & \multicolumn{2}{|c|}{ Proportions of Sulphur Sources (\%) } \\
\hline & & & & Seawater-Derived & Magmatic Origin \\
\hline \multicolumn{4}{|c|}{ MORB-hosted Duanqiao inactive field (SWIR 50.5 E) $6.6(n=8)$} & $24.8-49.5$ & $50.5-75.2$ \\
\hline 20V-S17-TVG7 & Bulk ore & 6.8 & & 31.6 & 68.4 \\
\hline 20V-S32-TVG14A-1 & $\mathrm{Py}+\mathrm{Mrc}$ & 6.0 & & 27.7 & 72.3 \\
\hline 20V-S32-TVG14A-2 & Ccp & 5.9 & $5.77(n=3)$ & 27.2 & 72.8 \\
\hline 20V-S32-TVG14A-3 & Sp & 5.4 & & 24.8 & 75.2 \\
\hline 20V-S32-TVG14B-1 & $\mathrm{Py}+\mathrm{Mrc}$ & 5.8 & & 26.7 & 73.3 \\
\hline 20V-S32-TVG14B-2 & $\mathrm{Sp}$ & 6.1 & $6.07(n=3)$ & 28.2 & 71.8 \\
\hline 20V-S32-TVG14B-3 & Bulk ore & 6.3 & & 29.1 & 70.9 \\
\hline 20VII-S12-TVG10 & Bulk ore & 10.5 & & 49.5 & 50.5 \\
\hline \multicolumn{4}{|c|}{ MORB-hosted Yuhuang inactive field (SWIR $49.2^{\circ}$ E) $5.8(n=5)$} & $21.8-33.0$ & $67.0-78.2$ \\
\hline 21VII-S35-TVG22-1 & $\mathrm{Py}+\mathrm{Po}$ & 4.8 & & 21.8 & 78.2 \\
\hline 21VII-S35-TVG22-2 & $\mathrm{Py}+\mathrm{Po}$ & 4.9 & & 22.3 & 77.7 \\
\hline 21VII-S35-TVG22-3 & Ccp & 6.4 & & 29.6 & 70.4 \\
\hline 21VII-S35-TVG22-4 & Sp & 5.8 & & 26.7 & 73.3 \\
\hline 21VII-S35-TVG22-5 & Py & 7.1 & & 33.0 & 67.0 \\
\hline \multicolumn{4}{|c|}{ Ultramafic-hosted Tianzuo inactive field (SWIR $63.5^{\circ}$ E) $7.0(n=4)$} & $1.0-46.1$ & $53.9-99.0$ \\
\hline 20VII-S25-TVG21-1 & Mrc & 9.3 & & 43.7 & 56.3 \\
\hline 20VII-S25-TVG21-2 & $\mathrm{Mrc}+\mathrm{Cv}$ & 9.8 & & 46.1 & 53.9 \\
\hline 20VII-S25-TVG21-3 & $\mathrm{Mrc}+\mathrm{Icb}$ & 8.4 & & 39.3 & 60.7 \\
\hline 20VII-S25-TVG21-4 & Icb & 0.5 & & 1.0 & 99.0 \\
\hline \multicolumn{4}{|c|}{ MORB-hosted Edmond hydrothermal field $\left(C I R 69.6^{\circ} E\right) 6.4(n=8)$} & $24.3-36.4$ & $63.6-75.7$ \\
\hline 17A-IR-TVG12-1 & Py & 5.3 & \multirow{4}{*}{$5.63(n=4)$} & 24.3 & 75.7 \\
\hline 17A-IR-TVG12-2 & $\mathrm{Sp}+\mathrm{Py}$ & 5.9 & & 27.2 & 72.8 \\
\hline 17A-IR-TVG12-3 & $\mathrm{Py}+\mathrm{Mrc}$ & 5.8 & & 26.7 & 73.3 \\
\hline 17A-IR-TVG12-4 & $\mathrm{Sp}$ & 5.5 & & 25.2 & 74.8 \\
\hline 19III-S18-TVG9-1 & Py & 6.2 & \multirow{4}{*}{$7.18(n=4)$} & 28.6 & 71.4 \\
\hline 19III-S18-TVG9-2 & $\mathrm{Py}+\mathrm{Mrc}$ & 7.3 & & 34.0 & 66.0 \\
\hline 19III-S18-TVG9-3 & $\mathrm{Ccp}+\mathrm{Py}$ & 7.4 & & 34.5 & 65.5 \\
\hline 19III-S18-TVG9-4 & Bulk ore & 7.8 & & 36.4 & 63.6 \\
\hline \multicolumn{4}{|c|}{ Ultramafic-hosted Kairei hydrothermal field $\left(C I R 70^{\circ}\right.$ E) $5.7(n=10)$} & $22.8-28.6$ & $71.4-77.2$ \\
\hline 19III-S12-TVG6-1 & $\mathrm{Ccp}+\mathrm{Bn}$ & 5.6 & & 25.7 & 74.3 \\
\hline 19III-S12-TVG6-2 & Ccp & 5.0 & & 22.8 & 77.2 \\
\hline 19III-S12-TVG6-3 & $\mathrm{Bn}$ & 5.5 & $5.65(n=5)$ & 25.2 & 74.8 \\
\hline 19III-S12-TVG6-4 & $\mathrm{Ccp}+\mathrm{Cv}_{\mathrm{v}}$ & 6.2 & & 28.6 & 71.4 \\
\hline 19III-S12-TVG6-5 & Bulk ore & 5.7 & & 26.2 & 73.8 \\
\hline 19III-S13-TVG7-1 & Py & 5.2 & & 23.8 & 76.2 \\
\hline 19III-S13-TVG7-2 & Ccp & 5.8 & & 26.7 & 73.3 \\
\hline 19III-S13-TVG7-3 & $\mathrm{Ccp}+\mathrm{Dg}$ & 5.9 & $5.72(n=5)$ & 27.2 & 72.8 \\
\hline 19III-S13-TVG7-4 & $\mathrm{Ccp}+\mathrm{Cv}$ & 6.1 & & 28.2 & 71.8 \\
\hline 19III-S13-TVG7-5 & Bulk ore & 5.6 & & 25.7 & 74.3 \\
\hline \multicolumn{4}{|c|}{ MORB-hosted EPR $13^{\circ} \mathrm{N}$ active hydrothermal vent field $2.7(n=2)$} & $7.3-15.5$ & $84.5-92.7$ \\
\hline EPR-TVG1 & $\mathrm{Py}+\mathrm{Mrc}$ & 3.5 & & 15.5 & 84.5 \\
\hline EPR-TVG2 & $\mathrm{Py}+\mathrm{Po}$ & 1.8 & & 7.3 & 92.7 \\
\hline \multicolumn{4}{|c|}{ MORB-hosted Niaochao active vent field (SEPR $\left.1-2^{\circ} S\right) 4.7(n=2)$} & $17.0-25.2$ & $74.8-83.0$ \\
\hline 20III-S4-TVG1A & Py & 5.5 & & 25.2 & 74.8 \\
\hline 20III-S4-TVG1B & $\mathrm{Py}+\mathrm{Ccp}$ & 3.8 & & 17.0 & 83.0 \\
\hline
\end{tabular}

Mineral abbreviations: $\mathrm{Bn}=$ bornite, $\mathrm{Ccp}=$ chalcopyrite, $\mathrm{Cv}=$ covelite, $\mathrm{Dg}=$ digenite, $\mathrm{Icb}=$ isocubanite, $\mathrm{Mrc}=$ marcasite, $\mathrm{Po}=$ pyrrhotite, $\mathrm{Py}=$ pyrite, $\mathrm{Sp}=$ sphalerite, $\mathrm{Wur}=$ wurtzite. ${ }^{*} \mathrm{~A}$ two-component mixing model is used to calculate the relative proportions of sulphur from different end-member sources, as proposed by [92].

\section{Discussion}

\subsection{Helium and Argon Sources}

Published analyses of noble gas isotopes show that helium and argon trapped in fluid inclusions have three potential sources. (1) Air-saturated water (ASW), including meteoric fluids and seawater, 
is characterised by atmospheric He and Ar isotopic compositions $\left({ }^{3} \mathrm{He} /{ }^{4} \mathrm{He}=1 \mathrm{R}_{\mathrm{a}},{ }^{40} \mathrm{Ar} /{ }^{36} \mathrm{Ar}=295.5\right)$. (2) Mantle volatiles, including most mantle-derived rocks, are produced from the upper oceanic mantle, which is characterised by a well-defined ${ }^{3} \mathrm{He} /{ }^{4} \mathrm{He}$ ratio of $1-1.3 \times 10^{-5}\left(7-9 \mathrm{R}_{\mathrm{a}}\right)$. At the same time, mantle-derived Ar is dominated by radiogenic ${ }^{40} \mathrm{Ar}$, with ${ }^{40} \mathrm{Ar} /{ }^{36} \mathrm{Ar}>40,000$ [93-95]. (3) $\mathrm{He}$ and $\mathrm{Ar}$ are also produced within the crust. High concentrations of large-ion lithophile elements (such as $U$ and $\mathrm{Th}$ ) in the continental crust can produce abundant radiogenic/nucleogenic Ar and $\mathrm{He}$, with ${ }^{40} \mathrm{Ar} /{ }^{36} \mathrm{Ar}$ ratios $\geq 45,000$ and ${ }^{3} \mathrm{He} /{ }^{4} \mathrm{He}$ ratios $\leq 0.1 \mathrm{R}_{\mathrm{a}}$, respectively [96], whereas the oceanic lithosphere accreted at mid-ocean ridges is composed mainly of mafic-ultramafic rocks which contain extremely low levels of radiogenic elements. As a result, ${ }^{3} \mathrm{He} /{ }^{4} \mathrm{He}$ ratios of oceanic crust approach to values of the upper mantle (6-9 $\left.R_{a}\right)$. Furthermore, it has been suggested that deep-sea water is characterised by lower ${ }^{3}$ He concentration but higher ${ }^{40} \mathrm{Ar}$ abundance when compared with the upper- and lower-mantle end members [42]. Therefore, variations in the mixture of different isotopic reservoirs can impart distinct He-Ar isotope compositions to the resulting hydrothermal products during ore-forming processes.

In this study, the ${ }^{3} \mathrm{He} /{ }^{4} \mathrm{He}$ ratios of most massive sulphide samples (except 20VII-S25-TVG21) ranged from $3.37 \mathrm{R}_{\mathrm{a}}$ to $10.0 \mathrm{R}_{\mathrm{a}}$. Notably, our results of the SWIR samples (with a mean value as high as $8.4 \mathrm{R}_{\mathrm{a}}, n=5$ ) are relatively greater than those obtained from the CIR and MAR hydrothermal precipitates (e.g., Edmond and Kairei: avg. 7.0 $\mathrm{R}_{\mathrm{a}}, n=3$; TAG: avg. $7.2 \mathrm{R}_{\mathrm{a}}$ [42]). All these results are more or less within the range of mantle-derived He (Figure 3), suggestive of mantle components as the main source of He. In particular, black smoker chimneys and $\mathrm{Fe}-(\mathrm{Zn})$-rich massive sulphides from the Longqi (19II-S7-TVG4B and 20V-S35-TVG17) and Yuhuang fields yield a high ${ }^{3} \mathrm{He} /{ }^{4} \mathrm{He}$ ratio of 9.10, 9.67, and $9.11 \mathrm{R}_{\mathrm{a}}$, respectively. These values are not only higher than the ratios of ${ }^{3} \mathrm{He} /{ }^{4} \mathrm{He}$ in the Indian Ocean Ridge basalts (avg. $8.49 \mathrm{R}_{\mathrm{a}}$ [35]), but also slightly higher than those of the upper-mantle fluids [97]. Thus, we suggest that a small amount of lower-mantle-derived He may contribute to the SWIR hydrothermal systems. At the same time, the input of marine-derived He should not be neglected. For example, some of the Edmond and Kairei sulphide ores have slightly lower ${ }^{3} \mathrm{He} /{ }^{4} \mathrm{He}$ ratios in contrast to those of the mafic-ultramafic host rocks, indicating a mixture of MORB with variable amounts of seawater-derived helium. It is interesting to note that marcasite-dominated sulphide samples from the ultramafic-hosted Tianzuo inactive field (associated with serpentinisation) exhibit uniformly low He-isotope values, which are very close to the ASW end member and significantly different from other vent fields along the ultraslow-spreading SWIR (Figure 3). Such a unique isotopic signature (1.12-1.88 $\mathrm{R}_{\mathrm{a}}$ ) can be easily explained by the dominance of a seawater-derived component due to pervasive low-temperature alteration in this area. Additionally, sub-seafloor extensive fluid circulation and mixing processes facilitated by local detachment faults may also play an important role in enhancing the entrainment of shallow seawater.

In most cases, the Ar isotopic ratios (ranging from 287.4 to 303.4) are generally in agreement with the modern atmospheric value (295.5) and, sometimes, just slightly lower or higher (Figure 4). Their values are considerably lower than those of MORB or OIB mantle end members, thus confirming that Ar is mainly derived from ambient deep-sea water, rather than from upper/lower mantle. This can be interpreted as evidence for a large proportion of seawater entrainment into submarine hydrothermal fluids [36]. However, the contribution from mantle-derived Ar cannot be completely ignored. Even minimal changes may occur in the Ar isotopic composition upon mixing with mantle-derived fluids because of the Ar solubility. Ar is soluble in aqueous fluid; thus, Ar concentration in the seawater $\left({ }^{36} \mathrm{Ar}\right.$ : $1.27 \times 10^{-6} \mathrm{~cm}^{3} \mathrm{STP} \cdot \mathrm{g}^{-1} ;{ }^{40} \mathrm{Ar}: 3.75 \times 10^{-4} \mathrm{~cm}^{3} \mathrm{STP} \cdot \mathrm{g}^{-1}$ [90]) is several orders of magnitude higher than that in the mantle ( ${ }^{36} \mathrm{Ar}: 2.7-6.5 \times 10^{-10} \mathrm{~cm}^{3} \mathrm{STP} \cdot \mathrm{g}^{-1} ;{ }^{40} \mathrm{Ar}: 3.3-7.6 \times 10^{-6} \mathrm{~cm}^{3} \mathrm{STP} \cdot \mathrm{g}^{-1}$ [98-100]) owing to its high solubility in seawater. Therefore, marine-derived Ar significantly influences the Ar isotopic compositions in hydrothermal sulphides. In contrast to Ar, the He concentration in mantle is much higher than that in seawater [90]. The contribution of mantle-derived fluid to He isotopic composition is more significant in polymetallic sulphides. As presented in Figure 4, hydrothermal precipitates show distinctive isotopic characteristics, implying that He is derived from the mantle. By contrast, Ar isotopic composition is similar to that in air. Analogous to the other 
hydrothermal fields, most of the He-Ar isotopic compositions in this study fall in the range of typical seafloor massive sulphide deposits with a slightly higher ${ }^{3} \mathrm{He} /{ }^{4} \mathrm{He}$. However, the majority of Tianzuo samples show an obvious departure from this range, owing to their unusually low ${ }^{3} \mathrm{He} /{ }^{4} \mathrm{He}$ ratios.

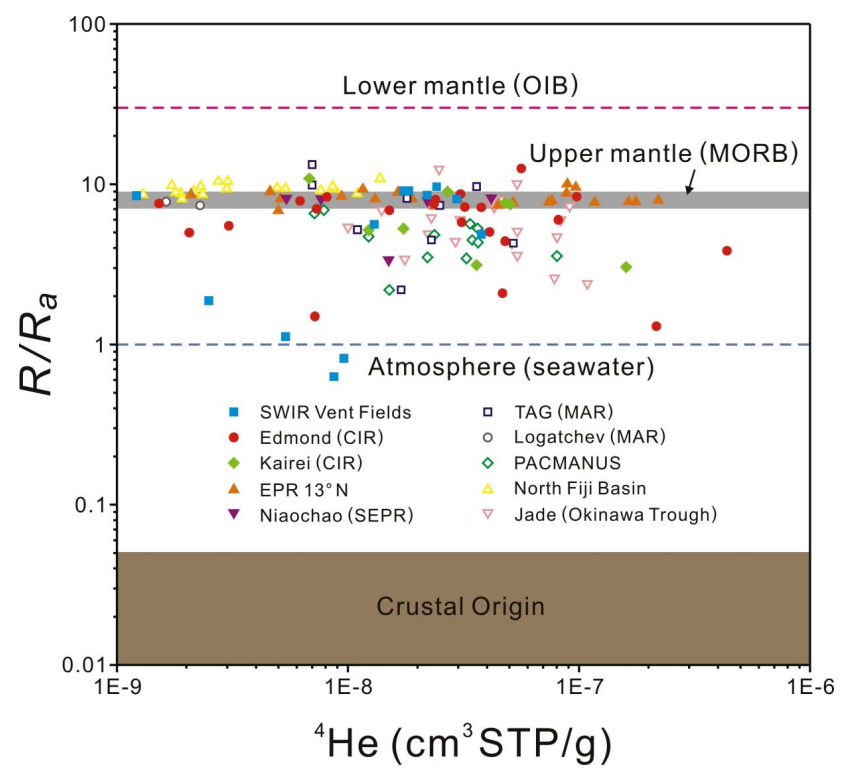

Figure 3. Scatter plots of $\mathrm{R} / \mathrm{R}_{\mathrm{a}}$ versus ${ }^{4} \mathrm{He}$ concentrations in polymetallic massive sulphides from active or inactive hydrothermal systems along the SWIR and CIR. Datapoints from other seafloor vent fields in different tectonic settings are also shown for comparison, given by [36,40-46,100-102].

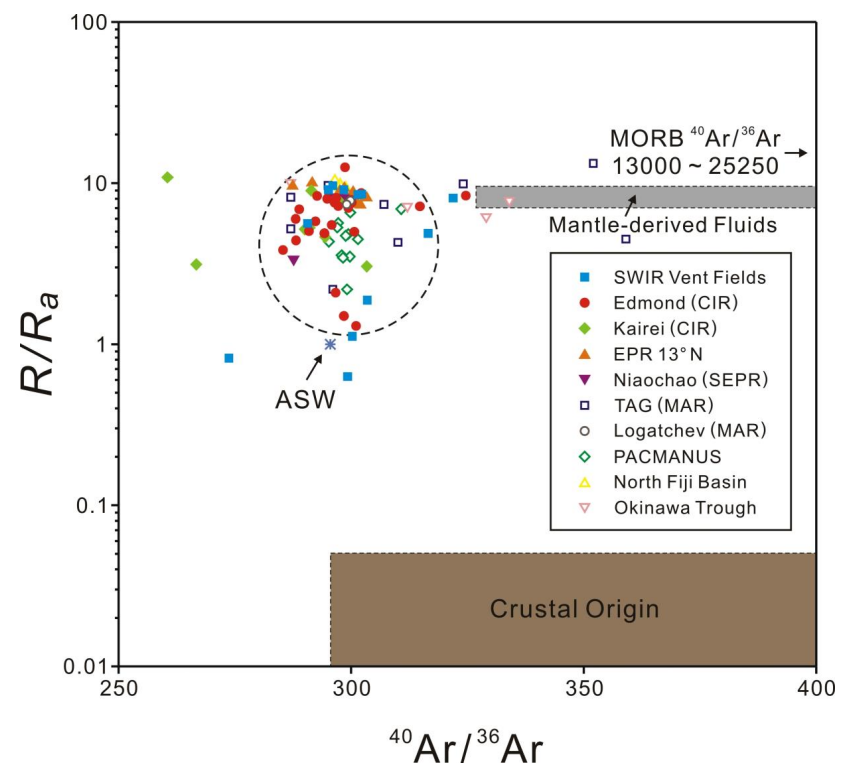

Figure 4. $R / R_{a}$ versus ${ }^{40} \mathrm{Ar} /{ }^{36} \mathrm{Ar}$ diagram of fluid inclusions hosted within massive sulphide samples from global seafloor hydrothermal vent fields (data sources from the previously published literature [36,40-46,100,102] and this study).

\subsection{Sulphur Sources}

Sulphide sulphur in global MOR hydrothermal vents can be derived from three main sources: (1) leaching from host rocks; (2) thermochemical reduction of seawater sulphate; and (3) leaching of sulphide minerals in sediments [50,51]. S-isotope compositions of hydrothermal precipitates reflect the combination of the processes of simple adiabatic mixing, thermochemical reduction, and/or dissolution of biogenic sulphide minerals. Previous investigations of basaltic-hosted massive sulphide 
deposits at mid-ocean ridges have shown a wide range of $\delta^{34} \mathrm{~S}$ ratios from $1 \%$ to $9 \%$ with a mean value of $4.5 \%$ [49-51]. In this study, bulk sulphur isotopic compositions of our MOR sulphide minerals fall into the abovementioned range. According to the S-isotope distribution in different vent fields, sulphur sources in polymetallic sulphides can be divided into three types [103]. The first type of sulphur source is mainly originating from MORB, and partially from reduced seawater sulphate. Several sediment-starved MOR hydrothermal fields (e.g., EPR $21^{\circ} \mathrm{N}$, southern Juan de Fuca Ridge, and Snakepit from the MAR) are characterised by such type. The second type consists of sulphur that mainly originates from sediments with a mixture of seawater-derived and/or organic sulphur. Sediment-hosted hydrothermal systems, such as Guaymas Basin and Middle Valley, belong to this type. Magmatic and sediment-derived S predominate the third type, also mixing with seawater-derived sulphur. This type consistently exists in hydrothermal fields from back-arc basin, such as the Jade vent field in Okinawa Trough $[103,104]$ (see Figure 5). Therefore, compared with hydrothermal systems at sediment-hosted MORs and back-arc basins, $\mathrm{S}$ sources are relatively simple in sediment-starved fields, mainly including seawater-derived sulphate and magmatic sulphur.

Overall, $\delta^{34} \mathrm{~S}$ in MORB-hosted sulphide deposits from the sediment-starved SWIR fall within a narrow range, varying from 3.0\% to 7.5\% (except 20VII-S25-TVG21). Such sulphur isotope features are somewhat similar to the TAG (Trans-Atlantic Geotraverse) hydrothermal field on the slow-spreading MAR [49]. We also note that the $\delta^{34} S$ values of the Longqi samples generally show a slight but significant increase, progressively from high-temperature to relatively low-temperature mineralisation stage. In some cases, the observed mineral zonation in a number of ore samples (e.g., 19II-S7-TVG4 and 20V-S35-TVG17) appears to be related to subtle changes in $\delta^{34}$ S with a heavier signature from the inner layers to exterior porous walls, implying a moderate admixture of magmatic $S$ and increasing proportions of seawater infiltrating into the chimney. Moreover, these results also indicate that most massive sulphides from the SWIR and CIR failed to reach isotopic equilibrium, the reason of which probably lies in their rapid co-precipitation upon mixing and cooling. This phenomenon (S-isotope disequilibrium) may be ubiquitous in hydrothermal fields along the Indian Ocean Ridges. Since pyrite/pyrrhotite should have higher $\delta^{34} S$ values than coexisting sphalerite and chalcopyrite under equilibrium conditions [105], the $\delta^{34} S$ data of some ore samples suggest strong isotopic disequilibrium between pyrite/pyrrhotite, sphalerite and chalcopyrite. Despite that, measured isotopic fractionation between them is negligibly small, particularly in chimney wall fragments or relict sulphide talus. This implies that fractionation did not occur because these minerals were deposited episodically at lower temperatures $\left(<350{ }^{\circ} \mathrm{C}\right)$. Although dissolution and replacement of pre-existing sulphate minerals may be common in some black smoker chimneys, heavy sulphur in pyrite-marcasite/covellite-bearing assemblages and $\mathrm{Si}-\mathrm{Fe}-\mathrm{Mn}$ oxyhydroxides is likely to have been predominantly derived from admixed seawater.

In general, sulphur isotopic data lying between two extreme values (MORB: $\delta^{34} \mathrm{~S} \approx \pm 0 \%$; seawater: $\delta^{34} \mathrm{~S} \approx+21 \%$ ) can be explained by non-equilibrium mixing between sulphur of basaltic origin and sulphur from reduced seawater $[106,107]$. Based on a two-component mixing model [92], we simply quantify the proportional contributions of seawater-derived and igneous sulphur to the SWIR hydrothermal precipitates. The mean $\delta^{34} S$ value of $5.1 \%$ for the Longqi massive ores $(n=16)$ indicates a seawater versus basalt $S$ ratio of about 23:77 on average. By contrast, heavier $S$ isotopes in colloform sulphide aggregates and silica chimney debris from the inactive Duanqiao, Yuhuang, and Tianzuo fields ( $\delta^{34} \mathrm{~S}$ up to $10.5 \%$ ) exhibit a larger contribution of sulphur derived from reduced seawater sulphate, ranging from approximately $22 \%$ to $50 \%$ (as listed in Table 3). In summary, the $\delta^{34} \mathrm{~S}$ values of the SWIR massive sulphides are relatively high in contrast to previously published data reported from the fast-spreading East Pacific Rise at $11^{\circ} \mathrm{N}, 13^{\circ} \mathrm{N}$ and $21^{\circ} \mathrm{N}[47,108]$ (see Figure 5). It has been suggested that the geological settings of ultraslow-spreading SWIR (especially for ultramafic-hosted vent systems) include a greater component of shallow seawater entrainment, pervasive low-temperature alteration, and sub-seafloor extensive hydrothermal circulation, when compared to fast-spreading centres $[55,109]$. Obviously, these processes are more 
conducive to thermochemical reduction of seawater sulphate, which imparts higher $\delta^{34} S$ values to the resulting sulphides. Our $\delta^{34} S$ results are generally consistent with precious integrated studies of $\mathrm{He}-\mathrm{Ar}$ isotopes and, thus, can provide geochemical evidence to support this conclusion.

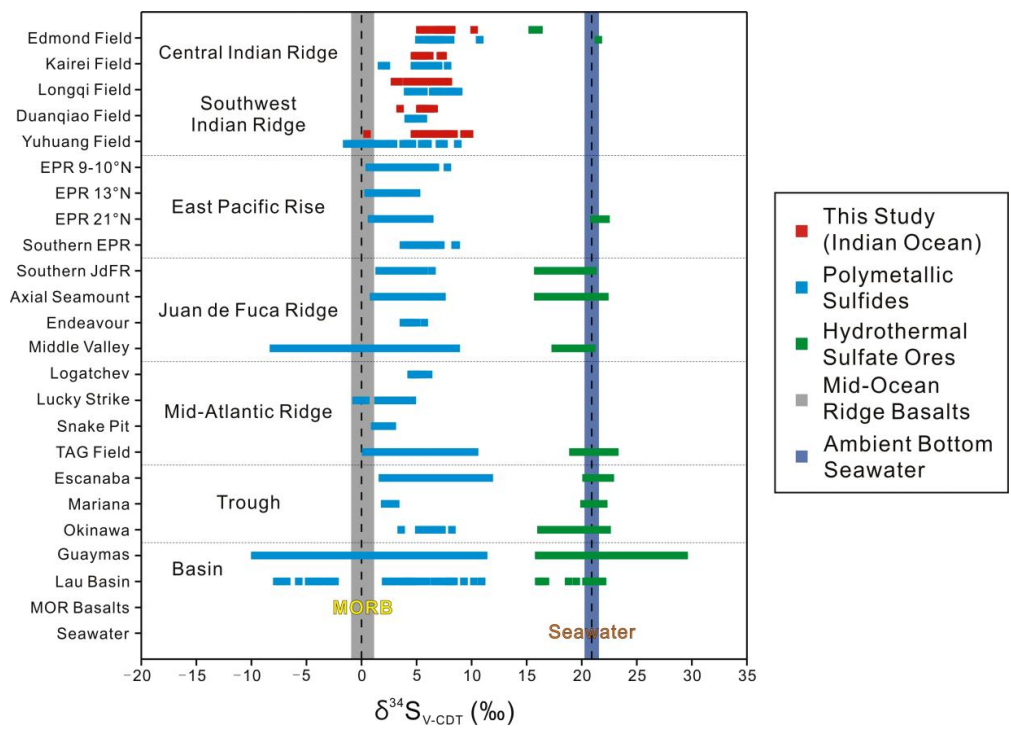

Figure 5. A comparison of variations in sulphur isotopic compositions of different hydrothermal sulphide deposits within a variety of tectonic settings on the modern seafloor (data sources from the published literature $[29,47-52,103,104,106-108]$ and this study).

\subsection{He-Ar-S Isotopic Constraints on the Proportional Contribution of Mantle Sources}

According to the $S$ isotopic data presented above, magmatic sulphur predominates as the major source of sulphur in our SWIR samples. On the other hand, seawater-derived sulphur accounts for $13 \%-35 \%$ in typical ore types from the Longqi, Duanqiao and Yuhuang fields. In relatively acidic environments with low oxygen fugacity, when these sulphide minerals directly precipitate from hydrothermal fluids, their $\mathrm{S}$ isotopic composition can represent that in the hydrothermal solution. As a result, up to $40 \%$ of hydrothermal fluid is derived from seawater with residues from the mantle. Given the minimal fractionation of $S$ isotope between the upper and lower mantle, $\delta^{34} S$ cannot reflect the proportions of upper and lower mantle in residual ore-forming fluids. However, an input of lower-mantle-derived He might be introduced to the SWIR hydrothermal products with higher ${ }^{3} \mathrm{He} /{ }^{4} \mathrm{He}$ ratios. Therefore, on the basis of boundary constraints deduced from the $\delta^{34} \mathrm{~S}$ ratios of seawater-derived ore-forming fluids, we can estimate the approximate proportions of the upper and lower mantle in hydrothermal fluids by using He-Ar isotopic tracers.

In S7-TVG4B, S35-TVG17, and S35-TVG22 samples, both S and He-Ar isotopic compositions have been analysed. Thus, specific results of certain minerals in corresponding samples were selected for calculation and further discussion. According to $\delta^{34} \mathrm{~S}$ values, seawater-derived component accounts for approximately $14 \%-27 \%$ of the SWIR ore-forming fluids. Thus, the residual is derived from the mixture of upper- and lower-mantle fluids. Assuming that the residual fluid is a dual mixed system by upper- and lower-mantle end members, we can simply quantify the proportional contribution of lower-mantle fluids $\left(\mathrm{He}_{\mathrm{LM}}\right)$ using a computing method modified after [110]:

$$
\begin{gathered}
\mathrm{He}_{\mathrm{LM}}(\%)=\left[\left({ }^{3} \mathrm{He} /{ }^{4} \mathrm{He}\right)_{\text {Sample }}-\left({ }^{3} \mathrm{He} /{ }^{4} \mathrm{He}\right)_{\mathrm{SW}} \times \mathrm{A}-\left({ }^{3} \mathrm{He} /{ }^{4} \mathrm{He}\right)_{\mathrm{UM}} \times(1-\mathrm{A})\right] \times \\
100 \% /\left[\left({ }^{3} \mathrm{He} /{ }^{4} \mathrm{He}\right)_{\mathrm{LM}}-\left({ }^{3} \mathrm{He} /{ }^{4} \mathrm{He}\right)_{\mathrm{UM}}\right]
\end{gathered}
$$

In this formula, the ratio of seawater-derived fluid is expressed as $\mathrm{A}$, which can be calculated by $\delta^{34} \mathrm{~S}$ values; $\left({ }^{3} \mathrm{He} /{ }^{4} \mathrm{He}\right)_{\mathrm{SW}}$ refers to the He isotope ratio in seawater, which equals to $1 \mathrm{R}_{\mathrm{a}}$ [97]; $\left({ }^{3} \mathrm{He} /{ }^{4} \mathrm{He}\right)_{\mathrm{UM}}$ represents the He isotope ratio in the upper mantle, close to the He isotopic ratio of 
Indian Ocean MORBs $\left(\sim 8.5 \mathrm{R}_{\mathrm{a}}\right)$ [35]; and $\left({ }^{3} \mathrm{He} /{ }^{4} \mathrm{He}\right)_{\mathrm{LM}}$ corresponds to the He isotope ratio in the lower mantle with a value of $32 R_{a}$ [111]. The estimation results indicate that lower-mantle-derived He may account for $7 \%-13 \%$ of the total mantle He sources, while $63 \%-79 \%$ of He is probably derived from the upper mantle. As a result, helium in the SWIR hydrothermal sulphides mainly originates from the upper mantle and to a lesser extent, mixed by seawater-derived and lower-mantle-derived fluid as well.

It has been reported that the enrichment of ${ }^{3} \mathrm{He}$ in hydrothermal sulphide samples from the Okinawa Trough may be attributed to lower-mantle-derived He rising to the upper mantle through mantle plume [112]; as magma is melted and lifted, the lower-mantle-derived He will be introduced into the hydrothermal systems. Likewise, the ultraslow-spreading SWIR is characterised by active hotspot-ridge interaction. Some authors have observed that the He isotopic ratios of some SWIR basalt glasses near the Bouvet mantle plume can reach as high as $14.2 \mathrm{R}_{\mathrm{a}}$ [113]. The results of Bouguer anomalies and stratigraphic data also confirm the existence of anomalous mantle between Indomed and Gallieni FZs, and incompatible-element-enriched lavas in the vicinity of the Indomed FZ differed from the other segments [67-69,71]. These characteristics can be related to the initiation of the Marion, Kerguelen and Crozet hotspots [114]. Mantle-derived materials (such as peridotites) are extensively exposed on the seafloor, revealing that the SWIR crust is generally thin [55,57]. Published studies show that magmatic activity had occurred in this area since 11-8 Ma, and provided massive magma output and heat sources, which were assumed to be related to the Crozet hotspot activity [72]. This conclusion implies that a minor proportion of lower-mantle-derived He may be added to the SWIR hydrothermal systems through the Marion and Crozet hotspot activities and, at the same time, mixed with seawater-derived and upper-mantle-derived He. Thus, the He isotopic compositions in three ore samples from the Longqi and Yuhuang fields are products of different mixtures by seawater, upper mantle, and lower mantle. Among them, the upper mantle might play a dominant role.

In summary, we propose a descriptive model with a schematic diagram illustrating the distribution features of He-Ar-S isotopic compositions and multiple sources of ore-forming fluids in hydrothermal systems at SWIR $49^{\circ}-51^{\circ}$ E (see Figure 6).

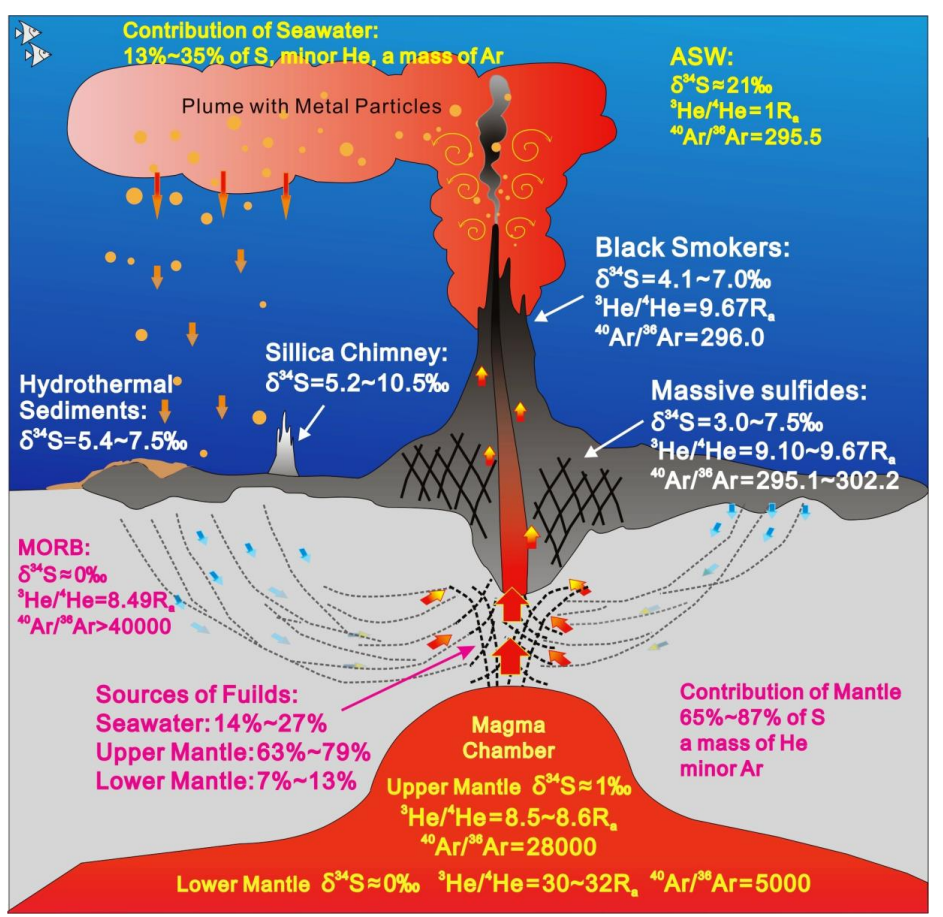

Figure 6. A diagram showing the distribution of $\mathrm{He}-\mathrm{Ar}-\mathrm{S}$ isotopic compositions and their contraints on the proportional contribution of multiple sources to an active hydrothermal vent system located on the ultraslow-spreading Southwest Indian Ridge between $49^{\circ}$ and $51^{\circ}$. 


\section{Conclusions}

(1) The $S$ isotopic ratios of typical massive sulphide samples in SWIR fall in a narrow range, varying from 3.0\% to 7.5\%. Seawater-derived and magmatic sulphur are dual sources of S during ore-forming processes, in which the contribution of magmatic sulphur plays a dominate role, approximately accounting for $65 \%-87 \%$ of total S sources, whereas the proportion of seawater-derived sulphur is about $13 \%-35 \%$. Additional contribution of seawater to No. S25-TVG21 sulphide samples $(45 \%-48 \%)$ indicates that the Tianzuo hydrothermal products had undergone extensive hydrothermal reworking, as well as post-depositional alteration by seawater. Sulphur sources in hydrothermal sulphides from the CIR are also characterised by the mixture of two end members dominated by magmatic sulphur.

(2) The $S$ isotopic ratios in the Longqi black smoker chimneys show that $\delta^{34} S$ in the exterior wall is higher than that in the inner portion, suggesting that the contribution of seawater increases from inner to outer layer. The results of $\delta^{34} S$ in most of the SWIR hydrothermal sulphides suggest that $S$ isotope failed to reach equilibrium due to their rapid precipitation when hydrothermal fluid mixed with seawater after venting.

(3) The ratios of ${ }^{3} \mathrm{He} /{ }^{4} \mathrm{He}$ in SWIR hydrothermal sulphides ranged from $9.67 \mathrm{R}_{\mathrm{a}}$ to $1.12 \mathrm{R}_{\mathrm{a}}$, along with ${ }^{40} \mathrm{Ar} /{ }^{36} \mathrm{Ar}$ ratios varying from $303.4 \mathrm{R}_{\mathrm{a}}$ to $290.6 \mathrm{R}_{\mathrm{a}}$. He isotopic compositions in three representative samples are the products of mixtures with variable amounts of seawater, and upper-mantle and lower-mantle components, among which, the upper mantle plays a dominant role. Ar isotopic analyses indicate that the majority of Ar in these SWIR samples is derived from seawater.

(4) According to He-S isotopic compositions, the sources of ore-forming fluids trapped in different types of hydrothermal precipitates can be roughly estimated. Our results indicate that upper-mantle-derived fluid accounts for $63 \%-79 \%$ and $14 \%-27 \%$ from seawater, whereas $7 \%-13 \%$ of $\mathrm{He}$ is derived from the lower mantle related to the Marion and Crozet hotspot activities. These isotopic signatures can provide useful insights into the impact of geological control on hydrothermal mineralisation at the ultraslow-spreading SWIR.

Author Contributions: Y.W., Z.W. and X.S. conceived and designed the experiments; Y.W. and Z.W. analyzed the data and wrote this paper; X.S., Z.W. and Y.G. have substantially revised the original manuscript; X.D. provided some SWIR sulphide samples for our study; L.X. contributed materials/analysis tools; Y.W., Y.H. and K.C. also made significant contributions to the sample preparation.

Funding: This research project was jointly funded by National Natural Science Foundation of China (Grant No. 41503036, 41702066, 41273054 and 41602092), National Key R \& D Program of China (2018YFC0309902), the doctoral program of Higher Education Research Fund (20120171130005), Guangdong Province Universities and Colleges Pearl River Scholar Funded Scheme (2011), the Fundamental Research Funds for Central Universities (No. 12lgjc05) and the China Ocean Mineral Resources Research and Development Association (DYXM-115-02-1-11).

Acknowledgments: We thank the crews and scientists of the DY115-19, DY115-20 and DY115-21 cruises on board the R/V Dayang Yihao, as well as China Ocean Sample Repository for providing these hydrothermal sulphide ores. We also gratefully acknowledge Hanbin Liu at the Analytical Laboratory of Beijing Research Institute of Uranium Geology and Guohao Jiang from Chinese Academy of Sciences for their assistance with He-Ar-S analyses.

Conflicts of Interest: The authors declare no conflict of interest.

\section{References}

1. Hannington, M.; Herzig, P.; Scott, S.; Thompson, G.; Rona, P. Comparative mineralogy and geochemistry of gold-bearing deposits on the mid-ocean ridges. Mar. Geol. 1991, 101, 217-248. [CrossRef]

2. Hannington, M.D.; Tivey, M.K.; Larocque, A.C.L.; Petersen, S.; Rona, P.A. The occurrence of gold in sulfide deposits of the TAG hydrothermal field, Mid-Atlantic Ridge. Can. Mineral. 1995, 33, 1285-1310.

3. Fouquet, Y.; Wafik, A.; Cambon, P.; Mevel, C.; Meyer, G.; Gente, P. Tectonic setting and mineralogical and geochemical zonation in the Snake Pit sulfide deposit (Mid-Atlantic Ridge at $\left.23^{\circ} \mathrm{N}\right)$. Econ. Geol. 1993, 88, 2018-2036. [CrossRef] 
4. Murphy, P.J.; Meyer, G. A gold-copper association in ultramafic-hosted hydrothermal sulfides from the Mid-Atlantic Ridge. Econ. Geol. 1998, 93, 1076-1083. [CrossRef]

5. Törmänen, T.O.; Koski, R.A. Gold enrichment and the Bi-Au association in pyrrhotite-rich massive sulfide deposits, Escanaba Trough, Southern Gorda Ridge. Econ. Geol. 2005, 100, 1135-1150. [CrossRef]

6. Nayak, B.; Halbach, P.; Pracejus, B.; Münch, U. Massive sulfides of Mount Jourdanne along the super-slow spreading Southwest Indian Ridge and their genesis. Ore Geol. Rev. 2014, 63, 115-128. [CrossRef]

7. Herzig, P.M.; Hannington, M.D.; Fouquet, Y.; von Stackelberg, U.; Petersen, S. Gold-rich polymetallic sulfides from the Lau back arc and implications for the geochemistry of gold in sea-floor hydrothermal systems of the Southwest Pacific. Econ. Geol. 1993, 88, 2182-2209. [CrossRef]

8. Binns, R.A.; Scott, S.D.; Bogdanov, Y.A.; Lisitzin, A.P.; Gordeev, V.V.; Gurvich, E.G.; Finlayson, E.J.; Boyd, T.; Dotter, L.E.; Wheller, G.E.; et al. Hydrothermal oxide and gold-rich sulfate deposits of Franklin Seamount, western Woodlark Basin, Papua New Guinea. Econ. Geol. 1993, 88, 2122-2153. [CrossRef]

9. Binns, R.A.; Parr, J.M.; Gemmell, J.B.; Whitford, D.J.; Dean, J.A. Precious metals in barite-silica chimneys from Franklin Seamount, Woodlark Basin, Papua New Guinea. Mar. Geol. 1997, 142, 119-141. [CrossRef]

10. Moss, R.; Scott, S.D. Geochemistry and mineralogy of gold-rich hydrothermal precipitates from the eastern Manus Basin, Papua New Guinea. Can. Mineral. 2001, 39, 957-978. [CrossRef]

11. Petersen, S.; Herzig, P.M.; Hannington, M.D.; Jonasson, I.R.; Arribas, A. Submarine gold mineralization near Lihir Island, New Ireland fore-arc, Papua New Guinea. Econ. Geol. 2002, 97, 1795-1813. [CrossRef]

12. Hannington, M.D.; Peter, J.M.; Scott, S.D. Gold in sea-floor polymetallic sulfide deposits. Econ. Geol. 1986, 81, 1867-1883. [CrossRef]

13. Herzig, P.M.; Hannington, M.D. Polymetallic massive sulfides at the modern seafloor: A review. Ore Geol. Rev. 1995, 10, 95-115. [CrossRef]

14. Hannington, M.D.; de Ronde, C.E.J.; Petersen, S. Sea-floor tectonics and submarine hydrothermal systems. Econ. Geol. 2005, 100, 111-141.

15. Halbach, P.; Blum, N.; Münch, U.; Plüger, W.; Garbe-Schönberg, D.; Zimmer, M. Formation and decay of a modern massive sulfide deposit in the Indian Ocean. Miner. Depos. 1998, 33, 302-309. [CrossRef]

16. Münch, U.; Blum, N.; Halbach, P. Mineralogical and geochemical features of sulfide chimneys from the MESO zone, Central Indian Ridge. Chem. Geol. 1999, 155, 29-44. [CrossRef]

17. Wang, Y.; Han, X.; Petersen, S.; Jin, X.; Qiu, Z.; Zhu, J. Mineralogy and geochemistry of hydrothermal precipitates from Kairei hydrothermal field, Central Indian Ridge. Mar. Geol. 2014, 354, 69-80. [CrossRef]

18. Wu, Z.; Sun, X.; Xu, H.; Konishi, H.; Wang, Y.; Wang, C.; Dai, Y.; Deng, X.; Yu, M. Occurrences and distribution of "invisible" precious metals in sulfide deposits from the Edmond hydrothermal field, Central Indian Ridge. Ore Geol. Rev. 2016, 79, 105-132. [CrossRef]

19. German, C.R.; Baker, E.T.; Mevel, C.; Tamaki, K. Hydrothermal activity along the Southwest Indian Ridge. Nature 1998, 395, 490-493. [CrossRef]

20. Münch, U.; Lalou, C.; Halbach, P.; Fujimoto, H. Relict hydrothermal events along the super-slow Southwest Indian spreading ridge near $63^{\circ} 56^{\prime} \mathrm{E}-$ Mineralogy, chemistry and chronology of sulfide samples. Chem. Geol. 2001, 177, 341-349. [CrossRef]

21. Bach, W.; Banerjee, N.R.; Dick, H.J.B.; Baker, E.T. Discovery of ancient and active hydrothermal systems along the ultra-slow spreading Southwest Indian Ridge $10^{\circ}-16^{\circ}$ E. Geochem. Geophys. Geosyst. 2002, 3, 1-15. [CrossRef]

22. Baker, E.T.; Edmonds, H.N.; Michael, P.J.; Bach, W.; Dick, H.J.B.; Snow, J.E.; Walker, S.L.; Banerjee, N.R.; Langmuir, C.H. Hydrothermal venting in magma deserts: The ultraslow-spreading Gakkel and Southwest Indian Ridges. Geochem. Geophys. Geosyst. 2004, 5, 1-29. [CrossRef]

23. Tao, C.; Lin, J.; Guo, S.; Chen, Y.J.; Wu, G.; Han, X.; German, C.R.; Yoerger, D.R.; Zhou, N.; Li, H.; et al. First active hydrothermal vents on an ultraslow-spreading center: Southwest Indian Ridge. Geology 2012, 40, 47-50. [CrossRef]

24. Tao, C.; Li, H.; Jin, X.; Zhou, J.; Wu, T.; He, Y.; Deng, X.; Gu, C.; Zhang, G.; Liu, W. Seafloor hydrothermal activity and polymetallic sulfide exploration on the Southwest Indian Ridge. Chin. Sci. Bull. 2014, 59, 2266-2276. [CrossRef]

25. Suo, Y.; Li, S.; Li, X.; Zhang, Z.; Ding, D. The potential hydrothermal systems unexplored in the Southwest Indian Ocean. Mar. Geophys. Res. 2017, 38, 61-70. [CrossRef] 
26. Tao, C.; Li, H.; Huang, W.; Han, X.; Wu, G.; Su, X.; Zhou, N.; Lin, J.; He, Y.; Zhou, J. Mineralogical and geochemical features of sulfide chimneys from the $49^{\circ} 39^{\prime}$ E hydrothermal field on the Southwest Indian Ridge and their geological inferences. Chin. Sci. Bull. 2011, 56, 2828-2838. [CrossRef]

27. Ye, J.; Shi, X.; Yang, Y.; Li, N.; Liu, J.; Su, W. The occurrence of gold in hydrothermal sulfide at Southwest Indian Ridge $49.6^{\circ}$ E. Acta Oceanol. Sin. 2012, 31, 72-82. [CrossRef]

28. Wang, Y.; Sun, X.; Wu, Z.; Deng, X.; Dai, Y.; Lin, Z. The enrichment characteristic and mechanism of gold-silver minerals in submarine hydrothermal sulfides from the ultraslow-spreading SWIR. Spectrosc. Spectr. Anal. 2014, 34, 3327-3332.

29. Liao, S.; Tao, C.; Li, H.; Barriga, F.J.A.S.; Liang, J.; Yang, W.; Yu, J.; Zhu, C. Bulk geochemistry, sulfur isotope characteristics of the Yuhuang-1 hydrothermal field on the ultraslow-spreading Southwest Indian Ridge. Ore Geol. Rev. 2018, 96, 13-27. [CrossRef]

30. Yuan, B.; Yu, H.; Yang, Y.; Zhao, Y.; Yang, J.; Xu, Y.; Lin, Z.; Tang, X. Zone refinement related to the mineralization process as evidenced by mineralogy and element geochemistry in a chimney fragment from the Southwest Indian Ridge at $49.6^{\circ}$ E. Chem. Geol. 2018, 482, 46-60. [CrossRef]

31. Ji, F.; Zhou, H.; Yang, Q.; Gao, H.; Wang, H.; Lilley, M.D. Geochemistry of hydrothermal vent fluids and its implications for subsurface processes at the active Longqi hydrothermal field, Southwest Indian Ridge. Deep-Sea Res. I 2017, 122, 41-47. [CrossRef]

32. Lupton, J.E.; Weiss, R.F.; Craig, H. Mantle helium in the Red Sea brines. Nature 1977, 266, 244-246. [CrossRef]

33. Turner, G.; Stuart, F. Helium/heat ratios and deposition temperatures of sulphides from the ocean floor. Nature 1992, 357, 581-583. [CrossRef]

34. Winckler, G.; Aeschbach-Hertig, W.; Kipfer, R.; Botz, R.; Rübel, A.P.; Bayer, R.; Stoffers, P. Constraint on origin and evolution of Red Sea brines from helium and argon isotopes. Earth Planet. Sci. Lett. 2001, 184, 671-683. [CrossRef]

35. Graham, D.W. Noble gas isotope geochemistry of Mid-Ocean Ridge and Ocean Island Basalts: Characterization of mantle source reservoirs. Rev. Mineral. Geochem. 2002, 47, 247-317. [CrossRef]

36. Zeng, Z.; Niedermann, S.; Chen, S.; Wang, X.; Li, Z. Noble gases in sulfide deposits of modern deep-sea hydrothermal systems: Implications for heat fluxes and hydrothermal fluid processes. Chem. Geol. 2015, 409, 1-11. [CrossRef]

37. Lupton, J.E.; Craig, H. A major helium-3 source at $15^{\circ} \mathrm{S}$ on the East Pacific Rise. Science 1981, $214,13-18$. [CrossRef] [PubMed]

38. Lupton, J.E.; Baker, E.T.; Massoth, G.J. Variable ${ }^{3} \mathrm{He} /$ heat ratios in submarine hydrothermal systems: Evidence from two plumes over the Juan de Fuca ridge. Nature 1989, 337, 161-164. [CrossRef]

39. Baker, E.T.; Lupton, J.E. Changes in submarine hydrothermal ${ }^{3} \mathrm{He} /$ heat ratios as an indicator of magmatic/tectonic activity. Nature 1990, 346, 556-558. [CrossRef]

40. Stuart, F.M.; Turner, G.; Duckworth, R.C.; Fallick, A.E. Helium isotopes as tracers of trapped hydrothermal fluids in ocean-floor sulfides. Geology 1994, 22, 823-826. [CrossRef]

41. Jean-Baptiste, P.; Fouquet, Y. Abundance and isotopic composition of helium in hydrothermal sulfides from the East Pacific Rise at $13^{\circ}$ N. Geochim. Cosmochim. Acta 1996, 60, 87-93. [CrossRef]

42. Zeng, Z.; Qin, Y.; Zhai, S. He, Ne and Ar isotope compositions of fluid inclusions in hydrothermal sulfides from the TAG hydrothermal field, Mid-Atlantic Ridge. Sci. China Ser. D Earth Sci. 2001, 44, 221-228. [CrossRef]

43. Zeng, Z.; Qin, Y.; Zhai, S. Helium, neon and argon isotope compositions of fluid inclusions in massive sulfides from the Jade hydrothermal field, Okinawa Trough. Acta Oceanol. Sin. 2004, 23, 655-661.

44. Lüders, V.; Niedermann, S. Helium isotope composition of fluid inclusions hosted in massive sulfides from modern submarine hydrothermal systems. Econ. Geol. 2010, 105, 443-449. [CrossRef]

45. Webber, A.P.; Roberts, S.; Burgess, R.; Boyce, A.J. Fluid mixing and thermal regimes beneath the PACMANUS hydrothermal field, Papua New Guinea: Helium and oxygen isotope data. Earth Planet. Sci. Lett. 2011, 304, 93-102. [CrossRef]

46. Wang, Y.; Han, X.; Qiu, Z. Source and nature of ore-forming fluids of the Edmond hydrothermal field, Central Indian Ridge: Evidence from He-Ar isotope composition and fluid inclusion study. Acta Oceanol. Sin. 2017, 36, 101-108. [CrossRef]

47. Bluth, G.J.; Ohmoto, H. Sulfide-sulfate chimneys on the East Pacific Rise, $11^{\circ}$ and $13^{\circ} \mathrm{N}$ latitudes. Part II: Sulfur isotopes. Can. Mineral. 1988, 26, 505-515. 
48. Herzig, P.M.; Hannington, M.D.; Arribas, A. Sulfur isotopic composition of hydrothermal precipitates from the Lau back-arc: Implications for magmatic contributions to seafloor hydrothermal systems. Miner. Depos. 1998, 33, 226-237. [CrossRef]

49. Herzig, P.M.; Petersen, S.; Hannington, M.D. Geochemistry and sulfur-isotopic composition of the TAG hydrothermal mound, Mid-Atlantic Ridge, $26^{\circ}$ N. Mar. Biogeol. 1998, 171, 47-70.

50. Shanks, W.C. Stable isotopes in seafloor hydrothermal systems: Vent fluids, hydrothermal deposits, hydrothermal alteration, and microbial processes. Rev. Mineral. Geochem. 2001, 43, 469-525. [CrossRef]

51. Seal, R.R. Sulfur isotope geochemistry of sulfide minerals. Rev. Mineral. Geochem. 2006, 61, $633-677$. [CrossRef]

52. Zeng, Z.; Ma, Y.; Chen, S.; Selby, D.; Wang, X.; Yin, X. Sulfur and lead isotopic compositions of massive sulfides from deep-sea hydrothermal systems: Implications for ore genesis and fluid circulation. Ore Geol. Rev. 2017, 87, 155-171. [CrossRef]

53. Dick, H.J.B.; Lin, J.; Schouten, H. An ultraslow-spreading class of ocean ridge. Nature 2003, 426, 405-412. [CrossRef] [PubMed]

54. DeMets, C.; Gordon, R.G.; Argus, D.F. Geologically current plate motions. Geophys. J. Int. 2010, 181, 1-80. [CrossRef]

55. Li, X.; Chu, F.; Lei, J.; Zhao, J. Advances in Slow-ultraslow-spreading Southwest Indian Ridge. Adv. Earth Sci. 2008, 23, 595-603.

56. Standish, J.J.; Sims, K.W.W. Young off-axis volcanism along the ultraslow-spreading Southwest Indian Ridge. Nat. Geosci. 2010, 3, 286-292. [CrossRef]

57. Zhou, H.; Henry, J. Thin crust as evidence for depleted mantle supporting the Marion Rise. Nature 2013, 494, 195-201. [CrossRef] [PubMed]

58. Gao, C.; Dick, H.J.B.; Liu, Y.; Zhou, H. Melt extraction and mantle source at a Southwest Indian Ridge Dragon Bone amagmatic segment on the Marion Rise. Lithos 2016, 246-247, 48-60. [CrossRef]

59. Grindlay, N.R.; Madsen, J.A.; Rommevaux-Jestin, C.; Sclater, J. A different pattern of ridge segmentation and mantle Bouguer gravity anomalies along the ultra-slow spreading Southwet Indian Ridge $\left(15^{\circ} 30^{\prime} \mathrm{E}\right.$ to $\left.25^{\circ} \mathrm{E}\right)$. Earth Planet. Sci. Lett. 1998, 161, 243-253. [CrossRef]

60. Cannat, M.; Rommevaux-Jestin, C.; Sauter, D.; Deplus, C.; Mendel, V. Formation of the axial relief at the very slow spreading Southwest Indian Ridge ( $49^{\circ}$ to $69^{\circ}$ E). J. Geophys. Res. Solid Earth 1999, 104, 22825-22843. [CrossRef]

61. Muller, M.R.; Minshull, T.A.; White, R.S. Segmentation and melt supply at the Southwest Indian Ridge. Geology 1999, 27, 867-870. [CrossRef]

62. Georgen, J.E.; Kurz, M.D.; Dick, H.J.B.; Lin, J. Low ${ }^{3} \mathrm{He} /{ }^{4} \mathrm{He}$ ratios in basalt glasses from the western Southwest Indian Ridge (10 $-24^{\circ}$ E). Earth Planet. Sci. Lett. 2003, 206, 509-528. [CrossRef]

63. Meyzen, C.M.; Toplis, M.J.; Humler, E.; Ludden, J.N.; Mével, C. A discontinuity in mantle composition beneath the Southwest Indian Ridge. Nature 2003, 421, 731-733. [CrossRef] [PubMed]

64. Seyler, M.; Cannat, M.; Mével, C. Evidence for major-element heterogeneity in the mantle source of abyssal peridotites from the Southwest Indian Ridge ( $52^{\circ}$ to $68^{\circ}$ E). Geochem. Geophys. Geosyst. 2003, 4, 1-33. [CrossRef]

65. Cannat, M.; Sauter, D.; Mendel, V.; Ruellan, E.; Okino, K.; Escartin, J.; Combier, V.; Baala, M. Modes of seafloor generation at a melt-poor ultraslow-spreading ridge. Geology 2006, 34, 605-608. [CrossRef]

66. Cannat, M.; Sauter, D.; Bezos, A.; Meyzen, C.; Humler, E.; Le Rigoleur, M. Spreading rate, spreading obliquity, and melt supply at the ultraslow spreading Southwest Indian Ridge. Geochem. Geophys. Geosyst. 2008, 9, 1-26. [CrossRef]

67. Sauter, D.; Patriat, P.; Rommevaux-Jestin, C.; Cannat, M.; Briais, A. The Southwest Indian Ridge between $49^{\circ} 15^{\prime}$ E and $57^{\circ}$ E: Focused accretion and magma redistribution. Earth Planet. Sci. Lett. 2001, 192, 303-317. [CrossRef]

68. Sauter, D.; Carton, H.; Mendel, V.; Munschy, M.; Rommevaux-Jestin, C.; Schott, J.-J.; Whitechurch, H. Ridge segmentation and the magnetic structure of the Southwest Indian Ridge (at $50^{\circ} 30^{\prime} \mathrm{E}, 55^{\circ} 30^{\prime} \mathrm{E}$ and $66^{\circ} 20^{\prime} \mathrm{E}$ ): Implications for magmatic processes at ultraslow-spreading centers. Geochem. Geophys. Geosyst. 2004, 5, 1-25. [CrossRef] 
69. Font, L.; Murton, B.J.; Roberts, S.; Tindle, A.G. Variations in melt productivity and melting conditions along SWIR (70 $\left.{ }^{\circ} \mathrm{E}-49^{\circ} \mathrm{E}\right)$ : Evidence from olivine-hosted and plagioclase-hosted melt inclusions. J. Petrol. 2007, 48, 1471-1494. [CrossRef]

70. Jian, H.; Singh, S.C.; Chen, Y.J.; Li, J. Evidence of an axial magma chamber beneath the ultraslow-spreading Southwest Indian Ridge. Geology 2017, 45, 143-146. [CrossRef]

71. Georgen, J.E.; Lin, J.; Dick, H.J.B. Evidence from gravity anomalies for interactions of the Marion and Bouvet hotspots with the Southwest Indian Ridge: Effects of transform offsets. Earth Planet. Sci. Lett. 2001, 187, 283-300. [CrossRef]

72. Sauter, D.; Cannat, M.; Meyzen, C.; Bezos, A.; Patriat, P.; Humler, E.; Debayle, E. Propagation of a melting anomaly along the ultraslow Southwest Indian Ridge between $46^{\circ} \mathrm{E}$ and $52^{\circ} 20^{\prime}$ E: Interaction with the Crozet hotspot? Geophys. J. Int. 2009, 179, 687-699. [CrossRef]

73. Zhang, T.; Lin, J.; Gao, J. Interactions between hotspots and the Southwest Indian Ridge during the last 90 Ma: Implications on the formation of oceanic plateaus and intra-plate seamounts. Sci. China Earth Sci. 2011, 54, 1177-1188. [CrossRef]

74. Zhang, T.; Lin, J.; Gao, J. Magmatism and tectonic processes in Area A hydrothermal vent on the Southwest Indian Ridge. Sci. China Earth Sci. 2013, 56, 2186-2197. [CrossRef]

75. Ren, M.; Chen, J.; Shao, K.; Zhang, S. Metallogenic information extraction and quantitative prediction process of seafloor massive sulfide resources in the Southwest Indian Ocean. Ore Geol. Rev. 2016, 76, 108-121. [CrossRef]

76. Han, X.; Wu, G.; Cui, R.; Qiu, Z.; Deng, X.; Wang, Y. Discovery of a hydrothermal sulfide deposit on the Southwest Indian Ridge at $49.2^{\circ}$ E. In Proceedings of the American Geophysical Union Fall Meeting 2010 Abstract \#OS21C-1531, San Francisco, CA, USA, 13-17 December 2010.

77. McCaig, A.M.; Cliff, R.A.; Escartin, J.; Fallick, A.E.; MacLeod, C.J. Oceanic detachment faults focus very large volumes of black smoker fluids. Geology 2007, 35, 935-938. [CrossRef]

78. Zhao, M.; Qiu, X.; Li, J.; Sauter, D.; Ruan, A.; Chen, J.; Cannat, M.; Singh, S.; Zhang, J.; Wu, Z.; et al. Three-dimensional seismic structure of the Dragon Flag oceanic core complex at the ultraslow spreading Southwest Indian Ridge (49³9’ E). Geochem. Geophys. Geosyst. 2013, 14, 4544-4563. [CrossRef]

79. Sun, C.; Wu, Z.; Tao, C.; Ruan, A.; Zhang, G.; Guo, Z.; Huang, E. The deep structure of the Duanqiao hydrothermal field at the Southwest Indian Ridge. Acta Oceanol. Sin. 2018, 37, 73-79. [CrossRef]

80. Yang, W.; Tao, C.; Li, H.; Liang, J.; Liao, S.; Long, J.; Ma, Z.; Wang, L. ${ }^{230} \mathrm{Th} /{ }^{238} \mathrm{U}$ dating of hydrothermal sulfides from Duanqiao hydrothermal field, Southwest Indian Ridge. Mar. Geophys. Res. 2017, 38, 71-83. [CrossRef]

81. Liang, Y.; Li, J.; Li, S.; Ruan, A.; Ni, J.; Yu, Z.; Zhu, L. The morphotectonics and its evolutionary dynamics of the central Southwest Indian Ridge $\left(49^{\circ}\right.$ to $51^{\circ}$ E). Acta Oceanol. Sin. 2013, 32, 87-95. [CrossRef]

82. Van Dover, C.L.; Humphris, S.E.; Fornari, D.; Cavanaugh, C.M.; Collier, R.; Goffredi, S.K.; Hashimoto, J.; Lilley, M.D.; Reysenbach, A.L.; Shank, T.M.; et al. Biogeography and ecological setting of Indian Ocean hydrothermal vents. Science 2001, 294, 818-823. [CrossRef] [PubMed]

83. Kumagai, H.; Nakamura, K.; Toki, T.; Morishita, T.; Okino, K.; Ishibashi, J.-I.; Tsunogai, U.; Kawagucci, S.; Gamo, T.; Shibuya, T.; et al. Geological background of the Kairei and Edmond hydrothermal fields along the Central Indian Ridge: Implications of their vent fluids' distinct chemistry. Geofluids 2008, 8, 239-251. [CrossRef]

84. Tao, C.; Lin, J.; Wu, G.; German, C.R.; Yoerger, D.R.; Chen, Y.J.; Guo, S.; Zeng, Z.; Han, X.; Zhou, N.; et al. First active hydrothermal vent fields discovered at the equatorial southern East Pacific Rise. In Proceedings of the American Geophysical Union, Fall Meeting 2008, Abstract \#V41B-2081, San Francisco, CA, USA, 15-19 December 2008.

85. Zeng, Z.; Chen, D.; Yin, X.; Wang, X.; Zhang, G.; Wang, X. Elemental and isotopic compositions of the hydrothermal sulfide on the East Pacific Rise near $13^{\circ}$ N. Sci. China Earth Sci. 2010, 53, 253-266. [CrossRef]

86. Cao, H.; Sun, Z.; Liu, C.; Jiang, X.; He, Y.; Huang, W.; Shang, L.; Wang, L.; Zhang, X.; Geng, W.; et al. The metallogenic mechanism and enlightenment of hydrothermal sulfide from the ultramafic-hosted hydrothermal systems at ultra-slow spreading ridge. Acta Oceanol. Sin. 2018, 40, 61-75.

87. Hu, R.; Bi, X.; Jiang, G.; Chen, H.; Peng, J.; Qi, Y.; Wu, L.; Wei, W. Mantle-derived noble gases in ore-forming fluids of the granite-related Yaogangxian tungsten deposit, Southeastern China. Miner. Depos. 2012, 47, 623-632. [CrossRef] 
88. Li, J.; Li, J.; Liu, H.; Zhang, J.; Jin, G.; Zhang, J.; Han, J. Helium isotope composition of inclusions in mineral grains using Helix SFT noble gas mass spectrometer. Acta Geol. Sin. 2015, 89, 1826-1831.

89. Xie, G.; Mao, J.; Li, W.; Zhu, Q.; Liu, H.; Jia, G.; Li, Y.; Li, J.; Zhang, J. Different proportion of mantle-derived noble gases in the $\mathrm{Cu}$-Fe and Fe skarn deposits: He-Ar isotopic constraint in the Edong district, Eastern China. Ore Geol. Rev. 2016, 72, 343-354. [CrossRef]

90. Allègre, C.J.; Staudacher, T.; Sarda, P. Rare gas systematics: Formation of the atmosphere, evolution and structure of the earth's mantle. Earth Planet. Sci. Lett. 1987, 81, 127-150. [CrossRef]

91. Jin, G.; Liu, H.; Zhang, J.; Li, J.; Han, J.; Wang, Y.; Zhang, J. EA-IRMS system measurement of stable sulfur isotope in sulphide. Uranium Geol. 2014, 30, 187-192.

92. Styrt, M.M.; Brackmann, A.J.; Holland, H.D.; Clark, B.C.; Pisutha-Arnond, V.; Eldridge, C.S.; Ohmoto, H. The mineralogy and the isotopic composition of sulfur in hydrothermal sulfide/sulfate deposits on the East Pacific Rise, $21^{\circ} \mathrm{N}$ latitude. Earth Planet. Sci. Lett. 1981, 53, 382-390. [CrossRef]

93. Patterson, D.B.; Honda, M.; McDougall, I. Noble gases in mafic phenocrysts and xenoliths from New Zealand. Geochim. Cosmochim. Acta 1994, 58, 4411-4427. [CrossRef]

94. Dunai, T.J.; Baur, H. Helium, neon and argon systematics of the European subcontinental mantle: Implications for its geochemical evolution. Geochim. Cosmochim. Acta 1995, 59, 2767-2783. [CrossRef]

95. Reid, M.R.; Graham, D.W. Resolving lithospheric and sub-lithospheric contributions to helium isotope variations in basalts from the southwestern US. Earth Planet. Sci. Lett. 1996, 144, 213-222. [CrossRef]

96. Andrews, J.N. The isotopic composition of radiogenic helium and its use to study groundwater movement in confined aquifers. Chem. Geol. 1985, 49, 339-351. [CrossRef]

97. Burnard, P.G.; Hu, R.; Turner, G.; Bi, X. Mantle, crustal and atmospheric noble gases in Ailaoshan gold deposits, Yunnan Province, China. Geochim. Cosmochim. Acta 1999, 63, 1595-1604. [CrossRef]

98. Staudacher, T.H.; Sarda, P.; Richardson, S.H.; Allègre, C.J.; Sagna, I.; Dmitriev, L.V. Noble gases in basalt glasses from a Mid-Atlantic Ridge topographic high at $14^{\circ} \mathrm{N}$ : Geodynamic consequences. Earth Planet. Sci. Lett. 1989, 96, 119-133. [CrossRef]

99. O'Nions, R.K.; Tolstikhin, I.N. Behaviour and residence times of lithophile and rare gas tracers in the upper mantle. Earth Planet. Sci. Lett. 1994, 124, 131-138. [CrossRef]

100. Stuart, F.M.; Turner, G. Mantle-derived ${ }^{40} \mathrm{Ar}$ in mid-ocean ridge hydrothermal fluids: Implications for the source of volatiles and mantle degassing rates. Chem. Geol. 1998, 147, 77-88. [CrossRef]

101. Hou, Z.; Zaw, K.; Li, Y.; Zhang, Q.; Zeng, Z.; Tetsuro, U. Contribution of magmatic fluid to the active hydrothermal system in the JADE field, Okinawa Trough: Evidence from fluid inclusions, oxygen and helium isotopes. Int. Geol. Rev. 2005, 47, 420-437.

102. Li, X.; Chu, F.; Lei, J.; Zhao, H.; Yu, X. Discussion on sources of metallogenic materials of hydrothermal sulfide from Southwest Indian Ridge: Isotope evidences. J. Earth Sci. Environ. 2014, 36, 193-200.

103. Zeng, Z.; Li, J.; Jiang, F.; Qin, Y.; Zhai, S. Sulfur isotopic composition of modern seafloor hydrothermal sediment and its geological significance. Acta Oceanol. Sin. 2002, 21, 519-528.

104. Zeng, Z.; Li, J.; Jiang, F.; Zhai, S.; Qin, Y.; Hou, Z. Sulfur isotopic composition of seafloor hydrothermal sediment from the Jade hydrothermal field in the central Okinawa Trough and its geological significance. Acta Oceanol. Sin. 2002, 21, 395-405.

105. Ohmoto, H. Systematics of sulfur and carbon isotopes in hydrothermal ore deposits. Econ. Geol. 1972, 67, 551-578. [CrossRef]

106. Rees, C.E.; Jenkins, W.J.; Monster, J. The sulphur isotopic composition of ocean water sulphate. Geochim. Cosmochim. Acta 1978, 42, 377-381. [CrossRef]

107. Sakai, H.; Des Marais, D.J.; Ueda, A.; Moore, J.G. Concentrations and isotope ratios of carbon, nitrogen and sulfur in ocean-floor basalts. Geochim. Cosmochim. Acta 1984, 48, 2433-2441. [CrossRef]

108. Arnold, M.; Sheppard, S.M.F. East Pacific Rise at latitude $21^{\circ}$ N: Isotopic composition and origin of the hydrothermal sulphur. Earth Planet. Sci. Lett. 1981, 56, 148-156. [CrossRef]

109. Li, X.; Chu, F.; Lei, J.; Zhao, J. Characterisitics of seafloor ultramafic-hosted hydrothermal systems and the implications. Mar. Geol. Quat. Geol. 2008, 28, 133-139.

110. Xu, Y.; Shen, P.; Tao, M.; Liu, W. Geochemistry on mantle-derived volatiles in natural gases from eastern China oil/gas provinces (I) A novel helium resource-Commercial accumulation of mantle-derived helium in the sedimentary crust. Sci. China Ser. D Earth Sci. 1997, 40, 120-129. [CrossRef] 
111. Marty, B.; Pik, R.; Gezahegn, Y. Helium isotopic variations in Ethiopian plume lavas: Nature of magmatic sources and limit on lower mantle contribution. Earth Planet. Sci. Lett. 1996, 144, 223-237. [CrossRef]

112. Hou, Z.; Li, Y.; Ai, Y.; Tang, S.; Zhang, Q. Helium isotopic compositions of the active hydrothermal system in the Okinawa trough: Evidence for the mantle-derived helium. Sci. China Ser. D Earth Sci. 1999, 29, 155-162.

113. Kurz, M.D.; Roex, A.P.L.; Dick, H.J.B. Isotope geochemistry of the oceanic mantle near the Bouvet triple junction. Geochim. Cosmochim. Acta 1998, 62, 841-852. [CrossRef]

114. Mahoney, J.; Le Roex, A.P.; Peng, Z.; Fisher, R.L.; Natland, J.H. Southwestern limits of Indian Ocean Ridge mantle and the origin of low ${ }^{206} \mathrm{~Pb} /{ }^{204} \mathrm{~Pb}$ mid-ocean ridge basalt-isotope systematics of the central Southwest Indian Ridge $\left(17^{\circ}-50^{\circ}\right.$ E). J. Geophys. Res. 1992, 97, 19771-19790. [CrossRef]

2018 by the authors. Licensee MDPI, Basel, Switzerland. This article is an open access article distributed under the terms and conditions of the Creative Commons Attribution (CC BY) license (http://creativecommons.org/licenses/by/4.0/). 